\title{
Poder regio y corregidores: justicia centralizada y toma de decisiones en el concejo de Ávila (1475-1500)*
}

\author{
José María Monsalvo Antón ${ }^{1}$ \\ Universidad de Salamanca \\ monsalvo@usal.es
}

RESUMEN: El presente trabajo analiza las relaciones entre el poder regio y el corregidor, en Ávila, en el reinado de los Reyes Católicos, intentando concretar el umbral del poder de este oficial en la práctica. Se ha evaluado toda la documentación referente al concejo de Ávila y su Tierra entre 1475 y 1500. Tras una aplicación cuantitativa y cualitativa de los métodos del proceso de toma de decisiones, se intenta demostrar que el corregidor, la máxima autoridad municipal, no era necesario para la intervención política de los reyes en las ciudades. El poder regio y los tribunales e instituciones centrales de la monarquía — corte, Audiencia Real, Consejo Real-disponian de recursos suficientes para hacer llegar sus politicas al concejo directamente o a través de otros oficiales, que convergieron con la actuación del corregidor.

Palabras Clave: Ávila; concejo; corregidor; Castilla; justicia
regia.

* Este trabajo se ha realizado en el marco del proyecto «Ciudad y nobleza en el tránsito a la Modernidad: autoritarismo regio, pactismo y conflictividad política. Castilla, de Isabel I a las Comunidades» (ref. HAR2017-83542-P), financiado por el Ministerio de Ciencia, Innovación y Universidades / AEI / FEDER 2018-2021.

Archivos utilizados: Archivo de la Chancillería, Valladolid (ACH), Registro de Ejecutorias; Archivo Municipal de Ávila, Ávila (AMA); Archivo General de Simancas, Simancas, Valladolid (AGS), Sección Registro General del Sello (RGS). En estos últimos casos, al ser documentación editada, se incluye en la bibliografía siguiendo la pauta correspondiente a esta.

1 ORCID iD: https://orcid.org/0000-0001-8258-772X 


\section{Royal power and Keepers of the City: centralized justice and decision-making in the Council of Ávila (1475-1500)}

ABSTRACT: This paper analyses the relations between royal power and the corregidor or Keeper of the City in Avila during the reign of the Catholic Monarchs, seeking to specify the practical extent of this officer's authority. All documentation concerning the Council of Ávila and its Land between 1475 and 1500 has been evaluated. After a quantitative and qualitative application of the methods involved in the decision-making process, an attempt is made to demonstrate that the corregidor, the highest municipal authority, was not necessary for the monarchs' political intervention in the cities. The royal power and the central courts and institutions of the monarchy - corte, Audiencia Real and Consejo Real-had sufficient resources to deliver their policies to the urban council directly or through other officers whose actions converged with those of the corregidor.

KeY wORDS: Ávila; council; Keepers of the City; Castilla; royal justice.

CÓMO CITAR ESTE ARTÍCULO / CITATION: Monsalvo Antón, José María, «Poder regio y corregidores: justicia centralizada y toma de decisiones en el concejo de Ávila (14751500)», Hispania, 81/268 (Madrid, 2021): 365-395. https://doi.org/10.3989/hispania.2021.010.

Los medievalistas especializados en historia concejil bajomedieval se encuentran invariablemente con una figura destacada, el corregidor, que se halla profusamente en documentos municipales del siglo XV. Desde el punto de vista del poder regio interesa también la figura como instrumento de su intervención en los municipios. El campo de estudio es tan amplio que conviene precisar qué se pretende en estas páginas.

Pues bien, como se trata de un acercamiento empírico, no hay lugar en ellas para consideraciones generales sobre las prerrogativas y atribuciones del oficio, ni para una interpretación global del mismo. El oficio ha sido estudiado tanto en trabajos clásicos como en otros recientes. Incluyendo acercamientos locales a esta figura, algunos de los cuales - referidos a ciudades de la meseta - se han tenido en cuenta aquí. Pero no pretendemos ahora entrar en cuestiones que han planteado esos y otros estudios, a los que nos remitimos ${ }^{2}$, sino sencillamente cuantificar y valorar escuetamente el caso de los corregidores abulenses durante período 1475-1500. El trabajo es un acercamiento al ejercicio práctico y concreto del oficio.

2 GONZÁlEZ ALONSO, 1970. BERMÚDEZ AZNAR, 1974. LUNENFELD, 1989. POLO MARTÍN, 1999. GUERRERO NARRARRETE, 1994-1995; 2000-2002. ASENJO, 2015; 2017. JARA FUENTE, 2017. MEMBRADO, 2014; 2018; 2019. 


\section{FUENTES Y MÉTODO}

El tratamiento de la información ha requerido una escrupulosa delimitación de la documentación utilizada y su gestión científica. El corpus analizado tenía que tener unos confines claros para que resultase adecuado para los intereses del estudio.

La documentación analizada responde a este propósito. Afortunadamente, la Institución Gran Duque de Alba lleva décadas publicando sistemáticamente documentación medieval del territorio histórico de la diócesis. Naturalmente, se incluye documentación del propio concejo de Ávila y su Tierra. Hay que mencionar al respecto la documentación tanto de la ciudad como de aldeas medievales de la Tierra de Ávila que cuentan con sus propios archivos. Igualmente, la documentación del antiguo Asocio, que recopiló privilegios y procesos judiciales referidos a los términos de Ávila su Tierra. Sin olvidar tampoco las Ordenanzas de Ávila³. A toda esta documentación, de corte municipal, se añade la procedente del Registro General del Sello. Es un amplísimo conjunto, del que se ha excluido lo referente a otros concejos diferentes al de Ávila: Arévalo, Madrigal, villas de Valdecorneja, villas del Tiétar y otros concejos señoriales $^{4}$. Este mismo criterio se ha seguido para la documentación del Registro de Ejecutorias de la Real Chancillería de Valladolid, tanto en relación con la documentación editada — hasta 1491 — como con la inédita ${ }^{5}$.

De la documentación abulense apenas ha quedado excluido del recuento algún documento de tipo privado o que no guarda relación con Ávila y su Tierra. Todo ello forma un corpus considerable de documentos, a cada uno de los cuales $^{6}$ se le ha otorgado un valor dentro de la tabla de contenidos.

${ }^{3}$ Documentación del Archivo Municipal de Ávila, 1988-1999. Documentación medieval del Archivo Municipal de San Bartolomé de Pinares..., 1987. Documentación medieval en Archivos Municipales Abulenses..., 1998 (lógicamente excluyendo en este caso los lugares que no eran de Ávila y su Tierra). Documentación medieval del Asocio..., 1990. Ordenanzas medievales de Ávila y su Tierra, 1990.

${ }^{4}$ Citaremos esta fuente de esta manera: Documentación medieval abulense en el RGS..., 1993-1998, seguido del volumen correspondiente y del documento concreto del mismo.

5 Aparecieron cuatro volúmenes en 2013 y la serie quedó detenida en la documentación referida a agosto de 1491. Para las ejecutorias inéditas, cerca de un centenar, entre septiembre de 1491 y 1500, recurrimos directamente al Archivo, ACH, Registro de ejecutorias.

${ }^{6}$ Hay tres pequeños fragmentos de Libros de actas, que abarcan muy pocos años y que contienen escuetos registros de actos concejiles (véase nota 30). Se computan como unidades documentales, que es el criterio seguido. Naturalmente, si un documento está repetido (ocurre a veces con Documentación del Archivo Municipal de Ávila, 1988-1999 y con Documentación medieval abulense en el RGS..., 1993-1998, vols. I-XVI), se computa una sola vez. Tanto en este caso como en general se ha optado por atribuir a cada documento un valor único susceptible de ser encuadrado en la tabla de ítems. Desde luego, hay otras posibilidades, como un análisis de secuencias decisionales que implique varios documentos —así se hizo para Alba de Tormes en 
Metodológicamente, se intentan analizar los procesos de toma de decisiones a partir del análisis sistémico. No aplicamos la teoría de sistemas con carácter general, sino concretamente como metodología de análisis decisional, complementario del análisis posicional y del análisis institucional, la tríada desde la que abordamos la cuestión. Desde esta óptica, analizamos cómo atravesaban el sistema concejil los diferentes flujos decisionales, observando su procedencia y su recorrido por el circuito concejil, hasta que el input inicial abandonaba el sistema, es decir, la salida o output. De este modo, independientemente de cuáles fueran las prerrogativas o atribuciones de cada oficio o posición institucional — que podrían ser meramente formales o genéricas - podemos estimar con precisión los respectivos roles decisionales y, en la práctica y de manera empírica, ciertos patrones, si los hubiera? Aunque podría ser aplicada a otros actores sociopolíticos - caballeros, relaciones del rey con los regidores, del rey con los pecheros, de los regidores con los pecheros...- - aquí la tabla sólo tiene en cuenta el análisis sistémico parcialmente, ya que se orienta exclusivamente a intentar apreciar específicamente el papel del corregidor. Este oficial era la máxima autoridad municipal y sus competencias eran amplísimas en el orden público y judicial. Este es el perfil institucional, jurídico y político general del oficio, como es bien sabido. Pero nos interesa aquilatar su rol decisional en la práctica, no a partir de sus prerrogativas y atribuciones oficiales. Por la experiencia de otros trabajos y situaciones, partimos de la hipótesis de que la estructura de poder concejil y del poder regio, aunque también recurrieron al corregidor, pudieron utilizar fluidamente en el último tercio del siglo $\mathrm{XV}$, y así lo hicieron, otros recursos directos diferentes, suficientemente potentes y operativos. Hasta el punto de que nos parece que para adoptar ciertas decisiones no era necesaria la implicación del corregidor, ya que había otras vías. Y que, en todo caso, la intervención del corregidor, cuando se producía, estaba fuertemente condicionada, cuando no era sencillamente orillada o supeditada a otros actores políticos.

\section{UNA PRIMERA APROXIMACIÓN CUANTITATIVA}

La tabla propuesta es una forma de ordenar los asuntos sobre los que se tomaron decisiones referentes a Ávila y su Tierra entre 1475 y $1500^{8}$. La tabla

varios capítulos del libro de MONSALVO, 1988-, y así convendría hacerlo para otras temáticas abulenses. Pero para determinar el marco de trabajo político del corregidor, al menos para un acercamiento que no tiene por qué ser definitivo, nos ha parecido suficiente este método que prima cada documento sobre los posibles racimos que pudieran aglutinar varios de ellos.

7 Véanse detalles de esta metodología en MONSALVO, 1988, especialmente los capítulos 12 y 13. En MONSALVO, 2003: 451-456 se resumen las ventajas del enfoque sistémico frente a los convencionales.

${ }^{8}$ El Anexo 1 no se ha construido siguiendo criterios de tipología diplomática - aunque se tienen en parte en cuenta—, sino más bien de contenidos adecuados a los objetivos heurísticos de este trabajo. 
es un instrumento, quizá algo tosco — podría haber otras posibilidades—, para aquilatar el papel de los corregidores. Desde luego, para hacerlo en el plano cuantitativo, si bien tanto ahora como en el siguiente epígrafe complementamos la perspectiva con un análisis cualitativo.

Anexo 1. Patrones de toma de decisiones en la documentación sobre Ávila y su Tierra, 1475-1500

\begin{tabular}{|c|c|c|c|c|c|}
\hline Patrones decisionales & $\mathbf{A}$ & B & $\mathbf{C}$ & $\mathbf{D}$ & $\mathbf{E}$ \\
\hline $\begin{array}{l}\text { [1] Nombramiento de regidores, renuncias y asuntos relativos al } \\
\text { ejercicio de estos oficios }\end{array}$ & 17 & & & & \\
\hline [2] Nombramiento de escribanos públicos & 31 & & & 4 & \\
\hline $\begin{array}{l}\text { [3] Nombramiento y prórrogas de corregidores y otros oficios de } \\
\text { justicia }\end{array}$ & 9 & & & 4 & \\
\hline $\begin{array}{l}\text { [4] Disposiciones sobre oficios de justicia, medidas de control y } \\
\text { juicio de residencia }\end{array}$ & 13 & 5 & 1 & & \\
\hline $\begin{array}{l}\text { [5] Concesión o confirmación de propiedades, privilegios sobre } \\
\text { titularidad de términos y lugares, jurisdicciones e inmunidades }\end{array}$ & 5 & 1 & & & \\
\hline $\begin{array}{l}\text { [6] Concesión de privilegios fiscales: hidalguías, libramientos, } \\
\text { exenciones y moratorias de pago }\end{array}$ & 43 & & & & \\
\hline $\begin{array}{l}\text { [7] Concesión de privilegios a Ávila y sus aldeas, o } \\
\text { reconocimiento genérico de los mismos }\end{array}$ & 6 & & & & 1 \\
\hline [8] Cartas de perdón & 13 & & & & \\
\hline [9] Medidas de amparo, seguro y protección & 37 & 7 & & & \\
\hline $\begin{array}{l}\text { [10] Otorgamiento de licencias y reconocimiento de derechos a } \\
\text { particulares sobre asuntos civiles y patrimoniales }\end{array}$ & 10 & & & & \\
\hline $\begin{array}{l}\text { [11] Legitimaciones de hijos naturales y tutela de huérfanos } \\
\text { menores }\end{array}$ & 9 & 3 & & & \\
\hline $\begin{array}{l}\text { [12] Exigencia de impuestos y gestión fiscal: plazos y condiciones } \\
\text { de entrega de lo recaudado en los impuestos regios (para la } \\
\text { guerra o para la hermandad. monedas, alcabalas...) }\end{array}$ & 46 & 16 & 10 & 10 & 15 \\
\hline $\begin{array}{l}\text { [13] Autorizaciones y gestión de cargas fiscales concejiles o } \\
\text { cuentas de índole local }\end{array}$ & 14 & 31 & 4 & 4 & 8 \\
\hline $\begin{array}{l}\text { [14] Provisiones y mandatos regios sobre probanzas y otras } \\
\text { actuaciones para incorporar a procesos judiciales en los } \\
\text { tribunales centrales: causas penales y civiles (familia y } \\
\text { herencias, abusos y violencias, contratos y bienes particulares, } \\
\text { corrupción) }\end{array}$ & 77 & 49 & 3 & & \\
\hline $\begin{array}{l}\text { [15] Provisiones y mandatos regios sobre probanzas y otras } \\
\text { actuaciones para incorporar a procesos judiciales en los órganos } \\
\text { y tribunales centrales: términos y jurisdicciones }\end{array}$ & 39 & 15 & 1 & & \\
\hline
\end{tabular}




\begin{tabular}{|c|c|c|c|c|c|}
\hline Patrones decisionales & $\mathbf{A}$ & B & C & D & $\mathbf{E}$ \\
\hline $\begin{array}{l}\text { [16] Actuaciones referidas a hidalguías, exenciones y criterios } \\
\text { de tributación }\end{array}$ & 21 & 15 & & & \\
\hline $\begin{array}{l}\text { [17] Provisiones y mandatos regios sobre probanzas y otras } \\
\text { actuaciones para incorporar a procesos judiciales en los órganos } \\
\text { y tribunales centrales: otros casos }\end{array}$ & 11 & 14 & 1 & & \\
\hline $\begin{array}{l}\text { [18] Actuaciones del Regimiento de Ávila, de los concejos } \\
\text { rurales y autoridades de la ciudad y la Tierra en el ejercicio de } \\
\text { sus competencias específicas }\end{array}$ & & & & 121 & \\
\hline $\begin{array}{l}\text { [19] Actuaciones por vía de gobierno o judicial del corregidor, o } \\
\text { su equivalente -su lugarteniente, un juez de residencia...- en el } \\
\text { ámbito de Ávila y su Tierra }\end{array}$ & & & & & 38 \\
\hline $\begin{array}{l}\text { [20] Procedimientos de ejecución o cumplimiento de normativa, } \\
\text { sentencias y mandatos regios en materia penal, por abusos y } \\
\text { violencias, corrupción pública y materias afines }\end{array}$ & 65 & 55 & 1 & & \\
\hline $\begin{array}{l}\text { [21] Procedimientos de ejecución o cumplimiento de normativa, } \\
\text { sentencias y mandatos regios sobre usurpaciones, términos y } \\
\text { jurisdicciones, o conflictividad derivada de ello }\end{array}$ & 41 & 52 & 5 & 5 & 6 \\
\hline $\begin{array}{l}\text { [22] Procedimientos de ejecución o cumplimiento de normativa, } \\
\text { sentencias y mandatos regios sobre préstamos, tributos, } \\
\text { herencias, obligaciones y contratos, propiedades y bienes } \\
\text { particulares }\end{array}$ & 124 & 40 & & & \\
\hline $\begin{array}{l}\text { [23] Procedimientos de ejecución o cumplimiento de normativa, } \\
\text { sentencias y mandatos regios sobre hidalguía y privilegios de } \\
\text { exención }\end{array}$ & 14 & 2 & & 2 & 5 \\
\hline $\begin{array}{l}\text { [24] Procedimientos de ejecución o cumplimiento de normativa, } \\
\text { sentencias y mandatos regios relacionados con las minorías } \\
\text { religiosas: ubicación en la ciudad, arrendamientos, usura, } \\
\text { situación de los bienes y préstamos que afectan a moros y judíos }\end{array}$ & 52 & 23 & & 3 & 1 \\
\hline $\begin{array}{l}\text { [25] Procedimientos de ejecución o cumplimiento de normativa, } \\
\text { sentencias y mandatos regios relacionados con asuntos eclesiásticos, } \\
\text { Inquisición y bienes confiscados, cruzada }\end{array}$ & 63 & 13 & & & \\
\hline $\begin{array}{l}\text { [26] Adopción de medidas en relación con la guerra y el } \\
\text { reclutamiento de tropas }\end{array}$ & 9 & 3 & 9 & 5 & 5 \\
\hline [27] Otros & 44 & 21 & 4 & 6 & 39 \\
\hline
\end{tabular}

A- Inputs desde el poder regio y órganos centrales sin que se requiera la intervención del corregidor de Ávila. B- Inputs desde el poder regio y órganos centrales en que se requiere expresamente la intervención del corregidor de Ávila. C- Inputs desde el poder regio y órganos centrales remitidos a las autoridades del concejo en general, o en concreto al Regimiento, a los concejos rurales o a otras instancias locales para que adopten ciertas medidas. D- Actuaciones y medidas adoptadas por el Regimiento, grupos de población o autoridades locales, promovidas por su propia iniciativa. E- Otros (intervenciones particulares, situaciones difíciles de determinar...), incluyendo —en el ámbito de su competencia- actuaciones del corregidor sin que conste expresamente un requerimiento del poder regio y órganos superiores. 
Los nombramientos de los regidores [1], con los relevos por fallecimiento o la autorización de renuncias, al margen de si en la práctica los ponía el Regimiento o los linajes ${ }^{9}$, era prerrogativa de los reyes, sin que los corregidores interviniesen ni de hecho ni de derecho.

Los nombramientos de escribanos públicos [2] procedían del poder superior sin intervención del corregidor, ya se tratase de escribanos de la ciudad, de los sexmos o - en los últimos años - de algún otro, como el de los secuestros de bienes por la Inquisición. Al margen de que los reyes asumieran peticiones particulares o de otro tipo, el nombramiento era siempre regio ${ }^{10}$ y el papel de los corregidores, nulo. Otra cuestión es que los regidores, al menos al principio del reinado de los Reyes Católicos, alegaran que los regidores tenían atribuciones para proponer a los reyes el relevo de las escribanías vacantes ${ }^{11}$.

El nombramiento de corregidores [3] recaía también exclusivamente en el poder regio. El oficio implicaba la «justicia de fecho» — orden público-y la «justicia juzgando» — judicial — en el ámbito municipal y solía conllevar oficios bajo sus órdenes: alcaldes y alguaciles ${ }^{12}$. Conocemos la identidad de todos los corregidores del período: Gonzalo Chacón aparece en 1475 como corregidor, pero actuó con lugartenientes, entre ellos Juan Chacón. Juan del Campo fue lugarteniente, luego actuó como corregidor y así aparece en 1476 y 1477. Aunque Gonzalo Chacón seguía teniendo el oficio nominalmente, ese año se cita a Juan Flores de Toledo, hasta su suspensión en 1479. En 1480 aparece Juan Pérez de Segura y, desde mayo, Pedro Sánchez de Frías, que ocupó también el cargo en 1481. Tras él, y luego tras Pedro del Lago y Francisco de Mendoza, en 1485 arraigó en el oficio Alonso de Portocarrero, cuyo mandato se extendió hasta septiembre de 1488. Entonces accedió al corregimiento el oidor de la Audiencia Álvaro de Santiesteban, que ocupó el oficio hasta 1493. Francisco de Vargas y el licenciado Rodríguez de la Rúa se mencionan en 1493. En 1494 estuvo este y Antón Rodríguez de Villalobos. Tras la residencia hecha por Francisco González del Fresno, fue el licenciado Juan Pérez de la Fuente, desde

9 Para la designación de regidores, hemos sostenido la concurrencia de principios «estamentales», «privados» y «linajísticos», cuestión abordada en otros sitios, pero no aquí. Véase MONSALVO, 2003: 444-445, 487, entre otros trabajos.

${ }^{10}$ Según el patrón A. Se documentan 31 casos de nombramientos de escribanos.

11 Mayo de 1475, Documentación del Archivo Municipal de Ávila, 1988-1999, docs. $148,150,154,155$, correspondientes a este año. Pero no se ponía en tela de juicio la prerrogativa regia. Se supone que los nombramientos recogían las propuestas de los regidores - respetándose turnos entre los linajes - , como se comprueba en ese caso (Documentación del Archivo Municipal de Ávila, 1988-1999, doc. 149), pero lo que consta desde entonces son los nombramientos regios, sin especificarse los procedimientos de petición previa. En todo caso, de una u otra forma, son decisiones en las que el corregidor carecía de atribuciones.

${ }_{12}$ En el nombramiento de Gonzalo Chacón, recurriendo a una fórmula — se dice- : que el nombrado tuviera «corregimiento e juzgado e alcaldías e alguaziladgo» de Avila y su Tierra, 2-5-1475, Documentación del Archivo Municipal de Ávila, 1988-1999, doc. 147. 
julio de 1495, quien se hizo con el oficio, y en él estuvo hasta comienzos de 1497. Entonces Francisco de Vargas ocupó en su segundo mandato el cargo y lo tuvo hasta 1499. Tras la residencia hecha por Adán de Valdés, el corregimiento recayó en junio de 1499 en Juan de Deza, prorrogado en junio de 1500 para otro año más.

El nombramiento del corregidor se ajustaba siempre al patrón de input unilateral regio, algo que se hace extensivo también a los jueces de residencia, encargados de evaluar la acción de los corregidores tras su mandato. En algunos documentos se encuentra uno de los pocos resquicios que quedaban a las fuerzas locales y al Regimiento en los nombramientos: quejarse por el ejercicio del cargo, proponer su revocación o solicitar una prórroga del mandato $^{13}$.

Las medidas de control de los oficiales de justicia, particularmente el corregidor, recaían también en el poder superior [4], como se constata en 13 documentos. Hay 5 casos en los que los reyes encomiendan al corregidor estas funciones. Más raro - un caso- es que se encomiende al Regimiento el envío de la documentación de la residencia hecha a un corregidor ${ }^{14}$.

El reconocimiento regio de propiedades y términos, o privilegios asociados a los mismos [5], era una esfera en la que la unilateralidad de la decisión del poder regio es manifiesta ${ }^{15}$. El corregidor quedaba fuera ${ }^{16}$.

La concesión de libranzas de maravedíes, privilegios fiscales o moratorias en el pago de impuestos [6] era prerrogativa regia ${ }^{17}$. Los privilegios podían

${ }^{13}$ Como ocurrió con la reprobación de Juan Chacón en 1475, Documentación del Archivo Municipal de Ávila, 1988-1999, docs. 151, 152, 157; o la petición en 1489 para que siguiera en su cargo Álvaro de Santiesteban, Documentación del Archivo Municipal de Ávila, 1988-1999, doc. 365 .

14 29-9-1488, Documentación medieval abulense en el RGS..., 1993-1998, vol. V, doc. 26.

15 Solían ser privilegios concernientes a la ciudad o a términos de las aldeas, aunque hay otras posibilidades, como el mercado franco de la ciudad, 8-12-1494, Documentación del Archivo Municipal de Ávila, 1988-1999, doc. 423.

${ }^{16}$ Tan sólo en una ocasión los reyes ordenan al corregidor que haga respetar los privilegios de término propio de la aldea de Navalmoral, que les habían dado los reyes anteriores, 3-31490, Documentación medieval abulense en el RGS..., 1993-1998, vol. VI, doc. 12

${ }^{17}$ Están en relación con ello las ejecutorias de los pleitos de hidalguía enviadas a Ávila y que forman parte del corpus analizado. En la concesión de hidalguías es evidente la exclusión del corregidor. A veces se hacía explícita, como cuando los reyes ordenaron al corregidor que no se entremetiera en estos pleitos, ya que eran los alcaldes de los hijosdalgo de la corte regia quienes los tendrían que resolver, 4-11-1495, Documentación medieval abulense en el RGS..., 1993-1998, vol. XI, doc. 107. Cualquiera de las ejecutorias sobre hidalguía, tanto de aldeas (valga la de Andrés de Cogollos, como ejemplo, 16-11-1495, ACH, Registro de ejecutorias, caja 93,3), como de la ciudad (valga el caso de Lope Gallego y consortes, 30-1-1496, ACH, Registro de ejecutorias, caja 108,5) corroboran dónde estaba el centro de decisión en esta materia. 
concederse a aldeas concretas ${ }^{18}$, al concejo de Ávila, o bien a grupos o a personas concretas, lo más habitual ${ }^{19}$. Cuando los reyes requerían la intervención del corregidor en estos asuntos se trataba de meras formalidades, como asegurarse de que se cumpliesen los privilegios. Las posiciones de los grupos de población, Regimiento de Ávila o concejos rurales, entre otros, se limitaban a quejas o a solicitud de aclaraciones o concreción. Y no requerían para ello la actuación del corregidor.

El otorgamiento de otros privilegios - a la ciudad, dotación de términos a los pueblos, etc. [7] — recayó en los reyes, al margen de documentar algún traslado obtenido por las partes.

Las cartas de perdón [8], o de amparo y protección [9], eran otorgadas por los reyes a particulares, tanto a sus personas como a sus bienes. La obligación del Regimiento y de todas las autoridades de respetarlas era de carácter genérico y no significaba una merma de la capacidad decisional regia en esta materia. Sólo en 7 documentos se confiaba al corregidor la salvaguarda de esa protección o amparo; en otras 37 ocasiones no se prescribía nada al respecto.

El reconocimiento de derechos patrimoniales o de otro tipo a particulares, o ciertas licencias para disponer de los bienes [10], incluidas algunas licencias de mayorazgos, eran también decisiones regias.

Otra rúbrica incluye la legitimación de los hijos naturales y sus derechos de herencia. Aunque sean asuntos diferentes, se han incluido en ella otras cuestiones relativas a la tutela y la protección de los huérfanos menores [11]. La legitimación de herederos - 6 de los 9 documentos que se refieren a ello- era una prerrogativa regia canalizada en decisiones unilaterales, mientras que en las medidas sobre tutela y derechos de los menores coexistían decisiones en las que no participó el corregidor - 3 casos-, mientras en otras - 3 documentadas - los monarcas le encomendaban encargarse del cumplimiento, o velar para que se cumplieran las condiciones decididas por el rey o los órganos centrales. En cualquier caso, las decisiones regias o centralizadas eran las determinantes.

${ }_{18}$ Y están definidas por el patrón A. como la exención —y valga de ejemplo— de las obligaciones de aportar materiales y trasporte a Ávila, concedida a Cardeñosa a petición de los religiosos de Berrocal (franciscanos, allí entonces asentados), 7-2-1475, Documentación medieval abulense en el RGS..., 1993-1998, vol. I, doc. 8.

${ }^{19}$ No detallamos aquí estos privilegios: consistían en moratorias en el pago de deudas y en la concesión de «excusados» a personas concretas o miembros de la élite social en general. Destacan algunos privilegios con carácter general, como el reconocimiento - tras largos pleitos- de la exención de los caballeros «castellanos» de Ávila, aquellos que podían demostrar tener caballo y armas reglamentarias, un privilegio que se remitía a la época de Alfonso X. Véase 11-8-1495, Documentación medieval en Archivos Municipales Abulenses..., 1998, doc. 16, El Tiemblo; 2-11-1495, Documentación del Archivo Municipal de Ávila, 1988-1999, doc.436; y 17-2-1496, Documentación medieval abulense en el RGS..., 1993-1998, vol. XII, doc. 14. 
La mayor parte de la gestión de los impuestos regios [12], que generaba documentación variada - plazos, penalizaciones por demora... - se materializaba en decisiones unilaterales regias. Estos inputs regios directos no sólo fueron el flujo más importante cuantitativamente, con 46 documentos, sino de contenido destacado, ya que en él se incluían tanto las órdenes dadas a oficiales responsables tesoreros, recaudadores en el distrito de Hermandad o de obispado... - como la exigencia de impuestos y condiciones generales de su cobro - alcabalas, Hermandad, etc. - , quedando en segundo plano el papel de los otros actores políticos ${ }^{20}$.

En las autorizaciones y gestión de cargas fiscales de tipo local [13], el protagonismo regio - aunque fuera a petición concejil - era rotundo: las autorizaciones para imponer algunas sisas o repartimientos extraordinarios - por insuficiencia de las rentas de propios concejiles, por gastos de pecheros fuera de lo previsto, compensación por supresión del mercado franco, entre otrosfueron decididas por el poder regio. El corregidor era habitualmente requerido -31 documentos-, pero apenas para aplicar o supervisar los procesos de recaudación de las cargas decididas por el poder regio.

Muchos documentos eran cartas regias enviadas a diversos oficiales durante la tramitación de los procesos judiciales que en la corte o en los tribunales centrales se estaban llevando a cabo: emplazamientos, cartas de receptoría donde se encomendaba a alguien poner en marcha diligencias judiciales, tales como probanzas o declaraciones de testigos en el ámbito correspondiente-, cartas compulsatorias - con una petición de escrituras o sentencias de un determinado proceso-, cartas de comisión, cartas requisitorias o incitativas - con un requerimiento para que se llevase a cabo una determinada actuación judicial, o para hacer recaer en la jurisdicción concejil una determinada parte de un proceso-, cartas inhibitorias - exigiendo que se abstuvieran de intervenir en el caso- - todo esto al margen de las cartas ejecutorias propiamente dichas $^{21}$. Hemos querido comprobar si en esos procedimientos - provisiones y

${ }^{20}$ El patrón A12 se impone. Amén de algunos traslados, documentos concejiles y de recaudadores -D12, E12 - fueron secundarios, y meramente administrativos, tanto el papel del corregidor para averiguaciones y supervisión del cumplimiento de las órdenes regias - B12-, como el de las autoridades concejiles — $\mathrm{C} 12$ - a quienes los reyes encargaban también a veces alguna tarea de mera gestión.

${ }^{21}$ En la tabla de procesos decisionales, para algunos asuntos sobre propiedades, contratos, términos y causas penales, hemos considerado como ítems diferenciados la fase en que se canalizaban desde Ávila hacia los tribunales centrales —ítems [14], [15] — de aquella en que ya se trataba de cumplir en el ámbito abulense las cartas ejecutorias o mandatos emitidos con posterioridad a las sentencias, o cuando se exigía el cumplimiento de normativa general del reino u otras órdenes regias - ítems [20], [21] y [22]—, es decir cuando se trataba de aplicar resoluciones y medidas decididas o resueltas ya previamente en las instancias centrales. Sin embargo, en relación con las hidalguías y tributación, la Mesta, las minorías y las jurisdicciones especiales - [16], [23], [24], [25]—, no hemos considerado necesario separar en la tabla las dos fases, ya que no es relevante para la evaluación del papel del corregidor. 
actuaciones previas a la sentencia- era requerida la presencia y actuación de los corregidores abulenses. Aunque las cartas regias contenían fórmulas estándar según la tipología y dependiendo de la materia juzgada, las instituciones externas concernidas fueron varias: la Contaduría Mayor de Hacienda para asuntos fiscales; los alcaldes de corte para causas penales; la Audiencia en cuestiones de términos y gran parte de las causas civiles; y el Consejo Real en otras causas, desde jurisdicciones, herencias y contratos a otros muchos casos en que se vieron implicadas diversas instituciones del reino. En todos estos documentos que afectan a procesos donde estaban implicadas la Corte, la Chancillería o el Consejo Real - $\mathrm{u}$ otras instancias centrales-, hemos distinguido $^{22}$ las actuaciones que estaban en tramitación y que debían resolverse en aquellas instancias. ¿Cuál fue en estas situaciones el papel del corregidor?

En uno de los ítems se incluye buena parte de los procesos civiles o penales en tramitación [14], un campo amplísimo donde destaca el hecho de que el flujo -receptorías, emplazamientos a las partes, compulsatorias, comisiones a oficiales...- remitía regularmente al protagonismo de las instancias judiciales centrales. Muchos de los 77 documentos de esta rúbrica en los que se dio la decisión unilateral regia se referían a casos de viudas y huérfanos que, según las Cortes - se dice varias veces en la documentación ${ }^{23}$ —, tenían derecho a acudir a los tribunales centrales directamente. También casos en los que el denunciante recelaba de la justicia local o de las influencias en la ciudad y conseguía llevar el caso, en primera instancia o en apelación, a los tribunales del rey para sortear el ámbito municipal. En casos muy concretos - 3 documentos - solicitaban los monarcas la cooperación de autoridades concejiles locales. Los corregidores fueron requeridos en 49 documentos de este ítem, pero casi siempre en funciones menores, de trámite, siendo quizá su más palmaria actuación la realización de pesquisas, pero que deberían remitir a los tribunales centrales. Otros procedimientos, bajo la misma pauta, se refieren a términos y jurisdicciones [15], que presentan un cuadro semejante al anterior y predominio absoluto - 39 - de inputs que no requirieron la intervención del corregidor. Pueden singularizarse por su parte las actuaciones sobre hidalguía, tributación o contribuyentes [16 ${ }^{24}$, en las que el papel del corregidor, al que sólo se recurría en algunas ocasiones - 14 frente a 22

${ }^{22}$ Véase nota anterior.

${ }^{23}$ En realidad, este derecho de acudir directamente a la corte y la justicia real que asistía a viudas, huérfanos y personas desvalidas había sido reconocido por los primeros Trastámara (Cortes de Toro de 1371, Cortes de los antiguos reinos de León y Castilla, 1863, tomo II: 205) y se mantuvo en la cultura jurisdiccional castellana, «Novísima Recopilación, lib. IV, tít. I, ley I», en Códigos españoles concordados y anotados, 1850, tomo VII: 407.

${ }^{24}$ No se incluyen en esta rúbrica [16] los privilegios de hidalguía, exención o moratorias, propiamente dichos - ítem [6] - , ni la exigencia y condiciones inherentes a los impuestos, o su gestión - [12], [13]—, sino tan sólo las diligencias judiciales y las actuaciones para resolver casos particulares y situaciones concretas en esta materia. 
en que no ocurre- - se limitó a llevar a cabo por orden superior algunas averiguaciones locales. Cabe añadir actuaciones sobre otros asuntos no especificados aquí, bien por ser infrecuentes - pequeñas infracciones urbanísticas, por ejemplo $^{25}$, o fraudes mercantiles ${ }^{26}$ - o bien casos indeterminados por falta de información precisa [17]. Es muy claro el resultado que ofrecen estos documentos: a menudo el corregidor no formaba parte de esos procedimientos, o lo hacía de una forma subsidiaria, ya que las resoluciones judiciales terminales se tomaban en la Audiencia, alcaldes de casa y corte o Consejo Real.

Las actuaciones de las fuerzas y autoridades locales llevadas a cabo en el ámbito competencial concejil [18] son muy heterogéneas. No hacemos aquí un seguimiento detallado de las mismas. Había, entre ellas, peticiones de sectores poblacionales muy concretos ${ }^{27}$, incluyendo a veces peticiones de las aljamas o de los pecheros ${ }^{28}$, o bien actuaciones del concejo en cumplimiento de sus obligaciones: nombrar procuradores de Cortes o alcaldes de Hermandad, escoger delegados para alguna misión en concreto, elección de representantes pecheros, defensa del patrimonio comunal frente a particulares u otras instituciones, envío de cartas a autoridades diversas sobre múltiples asuntos, etc. Aunque en algún caso fuera aludido el corregidor en estos documentos, en su condición de autoridad municipal presente, otras muchas veces no se le incluye en la decisión, puesto que en este tipo de iniciativas los actores eran las fuerzas y autoridades locales, con claro protagonismo del Regimiento ${ }^{29}$. Aunque es abundante ${ }^{30}$, e incluye las

25 20-11-1483, Documentación medieval abulense en el RGS..., 1993-1998, vol. III, doc. 15 y 12-3-1493, Documentación medieval abulense en el RGS..., 1993-1998, vol. VIII, doc. 26, entre otros casos en que no tuvo ningún papel el corregidor -A17-; o un caso de la aldea de Fuente el Saúz, en que sí se comisiona a este oficial —B17-: 7-10-1493, Documentación medieval abulense en el RGS..., 1993-1998, vol. IX, doc. 20.

${ }^{26}$ Fraudes de dos vecinos sobre pesas y medidas, 11-12-1494, ACH, Registro de ejecutorias, caja 78,24.

${ }^{27}$ En este ítem [D18] se computan las actuaciones locales, aunque la secuencia decisional no terminase aquí. Pero, como se indicó, se ha seguido el criterio de asignar un valor decisional a cada documento.

${ }^{28}$ Lógicamente, estos procesos de toma de decisiones formaban circuitos complejos donde las fuerzas sociales desempeñaban roles que, a menudo, se traducían en la adopción final de la decisión por quien tenía competencias para ello, incluyendo la capacidad indirecta, como solemos decir, de los pecheros de «hacer política sin estar en el gobierno», MONSALVO, 2003.

${ }^{29}$ Por eso se incluyen en este ítem y bajo el patrón decisional D. Ahora bien, si la actuación que se requería del Regimiento o del concejo en general - regidores, procuradores pecheros, etc.- era una exigencia del poder regio, o de los órganos centrales, expresamente incluida en una carta regia, tal actuación de las autoridades locales la hemos recogido y computado en la tabla, en cualquiera de los otros ítems - nombramientos, gestión tributaria, guerra, términos...- - y patrones decisionales - A, B, C- correspondientes a estas otras instancias superiores, pues era de estas de quienes partía la actuación concejil que se requería.

${ }_{30}$ Podría haberlo sido mucho más si se hubiesen conservado libros de acuerdos concejiles. Desgraciadamente, sólo se conservan fragmentos de libros de actas concejiles: 
ordenanzas locales ${ }^{31}$, hay que destacar que mucha documentación de este tipo era de trámite y pocas veces implicaba una decisión terminal en el Regimiento: recepción y registro de cartas regias - que habitualmente el concejo cumplía rutinariamente, escritos que se elevaban a los reyes, presentación de cartas de procuración, entre otras posibilidades.

Pocas veces se documenta al corregidor adoptando resoluciones si no era por exigencia superior, y pocas veces también aparece tomando iniciativas propias [19]. Es posible que hubiera a veces detrás una orden o requerimiento de los reyes. En todo caso, al no constar estos inputs externos en la unidad documental computada, tales iniciativas se han encuadrado dentro de este patrón decisional ${ }^{32}$.

Una buena parte de la documentación contiene cartas de ejecución de sentencias dictadas en los tribunales centrales. Pero además de las ejecutorias, técnicamente hablando, se incluyen en estos ítems otros mandatos, órdenes y provisiones regias para hacer cumplir medidas adoptadas en los órganos centrales, incluyendo leyes u otras decisiones superiores, no siempre judiciales. Se trata de comprobar en estos ítems cuál era el papel del corregidor en ese flujo ejecutivo de arriba hacia abajo. Distinguimos aquí varias materias, aunque no siempre es fácil la delimitación.

Por un lado, las ejecutorias y órdenes de cumplimiento referentes a abusos, delitos penales y de corrupción de oficiales ${ }^{33}$, que son bastante numerosas [20]. Por su parte, las ejecutorias y otras cartas regias sobre términos, jurisdicciones

octubre-noviembre 1496 Documentación del Archivo Municipal de Ávila, 1988-1999, doc. 455; 29-12-1496 a 31-12-1498, Documentación del Archivo Municipal de Ávila, 1988-1999, doc. 459; 17-1-1499 a 25-11-1499, Documentación del Archivo Municipal de Ávila, 1988-1999, doc. 492; y 18-1-1500 a 19-12-1500, Documentación del Archivo Municipal de Ávila, 1988-1999, doc. 510. Si en lugar de considerarlos como documentos sueltos, hubiésemos considerado cada una de las escuetas actuaciones registradas en cada fragmento conservado - respectivamente, $6,170,53$ y 72 pequeños apartados, según lo subdividen los editores de estos fragmentos de acuerdos concejiles, Gregorio Del Ser y José Miguel López Villalba—, el número hubiese sido naturalmente más alto. Y más, como decimos, si se hubiesen conservado los libros de acuerdos de todo el período. Pero aquí adoptamos el cómputo por unidad documental, no escindimos en partes cada documento. En cualquier caso, este tipo de actas municipales - hay un trabajo reciente sobre su contenido, LUCHÍA, 2018 - y su posible valoración cuantitativa no afecta apenas al propósito de este estudio, ya que su contenido se refiere a la vida municipal en sí, que hay que valorar en conjunto - MONSALVO, 2006-, mientras que en estas páginas nos interesa sólo la relación entre poder regio y corregidor.

31 Ordenanzas medievales de Avila y su Tierra, 1990, docs. 14-53.

32 E19, que se presenta mucho menos relevante que el de las actuaciones del corregidor que venían obligadas por inputs regios concretos. En efecto, otras actuaciones de los corregidores, si eran efecto de la exigencia desde otras instancias - mediante carta regia - no se computan aquí, sino en el patrón decisional $\mathrm{B}$, en los apartados correspondientes.

${ }_{33}$ No relativas a los procedimientos para que se resolvieran en otras instancias - [14] sino medidas dictadas ya para aplicarse o ejecutarse. 
y usurpaciones son también abundantes, máxime teniendo en cuenta que aquí hemos incluido además las coacciones o situaciones conflictivas que iban asociadas a estos procesos [21]. Aparte de actuaciones de particulares -6- de iniciativas concejiles, autónomas -5- o por encargo regio - 5-, destacan muchas actuaciones que los corregidores hicieron en cumplimiento de mandatos regios o sentencias centrales - 52-, aunque llama la atención el alto número de documentos en los que los reyes decidían en la materia - $41-\sin$ requerir actuaciones prácticas de ningún agente local. Además, estas actuaciones regias y centrales fueron las de mayor calado, como luego se indica.

Muchas disposiciones regias, mandatos y órdenes de ejecución dirigidos a particulares o a autoridades en general, que afectaban esencialmente a particulares en cuestiones de propiedad, contratos, herencias y cargas tributarias, conforman una parte importante del corpus documental [22], con 124 documentos entre los que destacan las ejecutorias. En menor medida, con 40 documentos, los reyes aparecen requiriendo alguna actuación de los corregidores, o sus equivalentes, en cumplimiento de las decisiones regias.

A propósito de algunas medidas relativas a alguna institución concreta, como la Mesta [23], hay unos pocos documentos donde el concejo o particulares podían intervenir, pero destacaba más el flujo unilateral regio, con 14 $\operatorname{casos}^{34}$, con casi irrelevante encargo de tareas al corregidor.

La existencia las minorías confesionales [24] dio lugar a muchas intervenciones regias. No sólo hemos incluido aquí las ejecutorias, sino también provisiones y procedimientos relacionados con judíos y moros. Los monarcas no delegaron en el ámbito concejil competencias significativas en esta materia. Aunque se fijaba que el concejo debía obedecer estas directrices regias, el protagonismo casi único en la fijación del estatuto de las minorías - en materia no sólo de deudas judías, sino de velas y rondas y otras obligaciones - correspondió al Estado central. No obstante, los monarcas delegaron en los corregidores cuestiones prácticas en asuntos como la formación de comisiones para la recaudación de la contribución de las aljamas judías, o para otras actuaciones menores, pero sin alterar la política que llevaban en el reino los monarcas en esta esfera.

34 Documentación medieval abulense en el RGS..., 1993-1998, vol. I, doc. 73, Documentación medieval abulense en el RGS..., 1993-1998, vol. III, doc. 17, Documentación medieval abulense en el RGS..., 1993-1998, vol. X, doc. 15; Documentación del Archivo Municipal de Ávila, 1988-1999, docs. 270, 272, 334; y Documentación medieval abulense en la Real Chancillería..., 2013, vol. III, doc. 14, entre otros documentos, incluidos en el patrón decisional A23. La documentación sobre delegaciones de alcaldes entregadores u otras personas y asuntos en relación con la Mesta, pero no cartas con órdenes regias, se incluye en el patrón E 23. En algún caso la actuación era responsabilidad de algún concejo de aldea -D23-, como cuando San Bartolomé de Pinares delimitaba pastos para no interferir en los itinerarios de la Mesta, Documentación medieval del Archivo Municipal de San Bartolomé de Pinares..., 1987, doc. 63 y 64. 
Igualmente, las provisiones y órdenes de ejecución que afectaban a asuntos eclesiásticos, Inquisición y cruzada se han agrupado en una rúbrica unitaria [25], dada su singularidad. También aquí el protagonismo de los inputs regios directos es rotundo, quedando el papel del corregidor reducido a cooperar en tareas subsidiarias.

Si se trataba de cuestiones que afectaban a asuntos como guerra, reclutamiento o materias estratégicas relacionadas con ello [26], aparte de documentos locales que no consistían en cargas fiscales regias, se observa que el poder regio, amén de los llamamientos generales a la guerra ${ }^{35}$, dirigió varias veces sus demandas directamente a los concejos ${ }^{36}$ sin solicitar la implicación del corregidor. Incluso este fue a veces ninguneado en la defensa militar de la propia ciudad ${ }^{37}$. En contadas excepciones exigieron al corregidor que hiciese algo ${ }^{38}$, mientras que en otras ocasiones observamos a otros oficiales - alcaldes, regidores u otras autoridades- comisionados para organizar los reclutamientos, levas, etc., de lo que se

${ }^{35}$ Que los reyes hacían unilateralmente, según el patrón A. Como por ejemplo el 15-11-1486. Documentación del Archivo Municipal de Ávila, 1988-1999, doc. 321, cuando los reyes convocaban a la guerra, en concreto a caballeros e hidalgos, para que se reunieran con sus armas en Córdoba en marzo de 1487; o en 1490, con un llamamiento a los hidalgos para la guerra de Granada, 8-12-1490, Documentación del Archivo Municipal de Ávila, 1988-1999, doc. 380; o un llamamiento general a hidalgos y caballeros de los concejos, 10-11-1496, Documentación medieval abulense en el RGS..., 1993-1998, vol. XII, doc. 48 y 23-11-1496 Documentación del Archivo Municipal de Ávila, 1988-1999, doc. 456. Son sólo unos ejemplos de este tipo de decisiones de los reyes en esta materia.

36 Según el patrón C: 10-4-1475, Documentación del Archivo Municipal de Ávila, 19881999, doc. 140; 7-6-1475, Documentación del Archivo Municipal de Ávila, 1988-1999, doc. 161; 20-11-1475, Documentación del Archivo Municipal de Ávila, 1988-1999, doc. 171; Documentación del Archivo Municipal de Ávila, 1988-1999, doc. 173 (la reina Isabel mandaba en 4-121475 que los caballeros y peones de Ávila fueran a Zamora a unirse con Fernando, sin mención alguna al corregidor); 25-12-1480, Documentación del Archivo Municipal de Ávila, 1988-1999, doc. 286 (la reina ordenaba al concejo organizar las lanças de acostamientos para 1481); 20-51482, Documentación del Archivo Municipal de Ávila, 1988-1999, doc. 293 (Fernando reclamaba al concejo de Fontiveros 300 peones para la guerra); 18-6-1489, Documentación del Archivo Municipal de Ávila, 1988-1999, doc. 360 (sobre reclutamiento de espingarderos); y 23-2-1496, Documentación del Archivo Municipal de Ávila, 1988-1999, doc. 440 (reclutamiento de peones).

${ }^{37}$ Como cuando la reina Isabel encomendó al obispo de Ávila, Alfonso de Fonseca, la «guarda» y defensa de Ávila, otorgándole todos los poderes - organizar las rondas, capacidad de destierro...-, dejando fuera al corregidor, 22-8-1475, Documentación del Archivo Municipal de Ávila, 1988-1999, doc. 166.

38 Patrón B26: 29-4-1475, Documentación del Archivo Municipal de Ávila, 1988-1999, doc. 146; en una leva de la población abulense para la guerra con Portugal, el rey Fernando le ordenaba que la organizase: «mando al corregidor de esa çibdad que vos acuçie e faga salir, al qual mando que vos faga luego partir e venir para mí», 16-5-1475, Documentación del Archivo Municipal de Ávila, 1988-1999, doc. 158; y 22-11-1475, Documentación del Archivo Municipal de Ávila, 1988-1999, doc. 172 (que custodiase prisioneros). 
desprende que el corregidor no era necesario para implementar la participación militar concejil.

Muchos de los asuntos del último ítem, «otros» [27], no incluidos en los anteriores, eran también objeto de inputs nacidos del poder central sin someterse a ningún control local: aparte de algunos pleitos de artesanos o vendedores por entrada, venta y derechos sobre mercancías ${ }^{39}$, hay que mencionar también como algo ajeno al corregidor la política monetaria regia, las medidas proteccionistas o de exportaciones - leyes de Cortes sobre saca de pan, cosas vedadas, etc ${ }^{40}$ - , las convocatorias de Cortes o las que hicieron para jurar a los herederos ${ }^{41}$, o bien medidas que afectaban a las instituciones concejiles o su funcionamiento y en las que el corregidor no era requerido ${ }^{42}$ salvo en contadas excepciones y siempre por orden regia ${ }^{43}$. Otra abundante documentación

${ }^{39} \mathrm{ACH}$, Registro de ejecutorias, caja 59,3; 59,15; 105,4; 110,39; y 117,8.

${ }_{40}$ No hace falta poner ahora ejemplos, porque es evidente. Son calificadas aquí normalmente bajo el patrón A27 o A22 - en este caso si afectaban a propiedades y bienes particulares - , aunque para tareas menores — meramente ejecutivas — sí se exigió a veces —B27— la intervención del corregidor o del concejo. Pero no fue lo habitual.

${ }^{41}$ Con un patrón A: 7-2-1475, Documentación del Archivo Municipal de Ávila, 1988-1999, doc. 132; 2-6-1475, Documentación del Archivo Municipal de Ávila, 1988-1999, doc.160; 13-11-1478, Documentación del Archivo Municipal de Ávila, 1988-1999, doc. 241; 22-5-1479, Documentación del Archivo Municipal de Ávila, 1988-1999, doc. 251; 16-3-1498, Documentación del Archivo Municipal de Ávila, 1988-1999, doc. 476; y 5-12-1498, Documentación del Archivo Municipal de Ávila, 1988-1999, doc. 486, entre otros.

${ }_{42}$ Algunos ejemplos a continuación. Los Reyes Católicos daban permiso a los pecheros de la Tierra para celebrar tres juntas al año, 9-3-1477, Documentación medieval abulense en el RGS..., 1993-1998, vol. I, doc. 52 y Documentación del Archivo Municipal de Ávila, 1988-1999, doc. 218. Exigencia al concejo para que hiciera cumplir la obligación de los corregidores y oficios de justicia, al jurar sus cargos, a respetar las ordenanzas del concejo, 27-6-1477, Documentación medieval abulense en el RGS..., 1993-1998, vol. I, doc. 59. Regulación de las reuniones del consistorio, 21-9-1479, Documentación medieval abulense en el RGS..., 1993-1998, vol. II, doc. 4. La obligación de hacer una casa consistorial, siguiendo lo aprobado por las Cortes, 20-3-1484, Documentación del Archivo Municipal de Ávila, 1988-1999, doc. 309 (y, Documentación medieval abulense en el RGS..., 19931998, vol. III, doc. 27). Cuando tomaban medidas para solucionar problemas (de orden público, de corruptelas o dádivas, de malas prácticas) detectados tras una visitación (Documentación del Archivo Municipal de Ávila, 1988-1999, doc. 288) de un delegado regio (no el corregidor) en la ciudad, 3-4-1487, Documentación del Archivo Municipal de Ávila, 1988-1999, doc. 326. Prohibiendo al concejo de Ávila en 1494 reunirse en la basílica de San Vicente en lugar del sitio habitual de San Juan, Documentación medieval abulense en el RGS..., 1993-1998, vol. X, doc. 111. Exigiendo al Regimiento que no impidiera al Común de la ciudad elegir un procurador nuevo, tras la muerte violenta del anterior, 7-31495, Documentación del Archivo Municipal de Ávila, 1988-1999, doc. 427 y Documentación medieval abulense en el RGS..., 1993-1998, vol. XI, doc. 31.

${ }^{43}$ Donde el patrón es del modelo B27. A propósito del caso de la muerte violenta del procurador del Común en 1495 (véase nota anterior), los reyes, a petición de los pecheros, se vieron obligados a pedir al corregidor que apremiase a aceptar el oficio a quienes el 
incluida en esta rúbrica se refiere a particulares que disputaban por algunos derechos o bienes, o que pedían traslados, presentaban títulos de propiedad o cartas variadas, o informaban al concejo de Ávila o a otras autoridades de asuntos de trámite ${ }^{44}$.

\section{Algunas CONSIDERACIONES Más SOBRe El PAPEL DEL CORREgIDOR}

Es evidente que el oficio de corregidor disponía de amplísimas atribuciones y prerrogativas, incluyendo el hecho de ser la máxima referencia judicial en el ámbito municipal. A veces el poder regio corroboraba estas prerrogativas ${ }^{45}$.

Sin embargo, la praxis decisional no se corresponde exactamente con el teórico umbral competencial del corregidor. Del examen de la documentación abulense entre 1475 y 1500 hemos extraído una importante evidencia y es que el corregidor no era necesario para la intervención del poder superior en los concejos $^{46}$. A las evidencias cuantitativas del epígrafe anterior, podemos añadir ahora otras consideraciones para subrayar esta aserción general.

Común eligiera, o a quien este eligiera además para otra tarea que tampoco nadie quería aceptar entonces, la de cobrar las contribuciones de la Hermandad, por temor a sufrir daños, 14-4-1495, Documentación del Archivo Municipal de Ávila, 1988-1999, doc. 430 y 14-4-1495, Documentación medieval abulense en el RGS..., 1993-1998, vol. XI, doc. 58; o le ordenaban que hiciese construir un arca para custodiar los privilegios concejiles, 21-81495, Documentación medieval abulense en el RGS..., 1993-1998, vol. XI, doc. 92; o que se encargase de que construyesen la casa del Ayuntamiento, 3-3-1497, Documentación del Archivo Municipal de Ávila, 1988-1999, doc. 462 y Documentación medieval abulense en el $R G S . . ., 1993-1998$, vol. XIII, doc. 13; o que facilitase la presencia del procurador pechero en las reuniones del Regimiento, ya que algunos ponían trabas, 3-3-1497, Documentación medieval abulense en el RGS..., 1993-1998, vol. XIII, doc. 14; o que se habilitase en el convento de San Francisco un espacio a modo de archivo para las escrituras de los pecheros, 21-6-1497, Documentación del Archivo Municipal de Ávila, 1988-1999, doc. 465 y Documentación medieval abulense en el RGS..., 1993-1998, vol. XIII, doc. 38; o le ordenaban que obligase a los regidores a asistir a las reuniones del concejo, 11-1-1498, Documentación medieval abulense en el RGS..., 1993-1998, vol. XIV, doc. 2. Pero era siempre cumpliendo órdenes concretas regias.

${ }^{44}$ Los hemos computado en el patrón D o E.

45 En asuntos incluso delicados, como eran por ejemplo los referentes a los judíos abulenses, en este caso haciendo frente a los intentos de injerencia jurisdiccional en el ámbito local del rabino mayor de Castilla Abraham Senior, como muestra la carta del rey, 15-11-1479, Documentación del Archivo Municipal de Ávila, 1988-1999, doc. 258. En la práctica, en los asuntos de minorías el corregidor tampoco resultó determinante. La causa de ello es que en estos asuntos fundamentalmente decidieron los reyes, no tanto la jurisdicción autónoma de las aljamas de Castilla.

${ }^{46}$ Hace ya tiempo habíamos sugerido este rol decisional del corregidor, concretamente al analizar los procesos decisionales de un concejo señorial, Alba de Tormes, en el primer tercio del siglo XV, MONSALVO, 1988. La situación de un gran concejo urbano de realengo en el 
En primer lugar, se comprueba que existían muchísimos asuntos que en la época entraban plenamente en la esfera de la política centralizada de la monarquía y que dejaban poco margen para el corregidor. Aparte de numerosas materias de exclusivo protagonismo regio - nombramientos, cartas de perdón, cartas de seguro, legitimaciones, concesión de privilegios... - es evidente que los reclutamientos militares, la política monetaria, la imposición fiscal general, la política económica general, pero también la Mesta, las minorías y otras muchas materias, se decidían por leyes y pragmáticas fuera del ámbito concejil.

En segundo lugar, el papel del corregidor era secundario - mera pieza o eslabón- en los procesos decisionales generales, aunque afectasen al ámbito concejil. En muchas materias no había competencias municipales apenas, como se acaba de decir. Pero es cierto que existían algunas, y a veces se encargaba al corregidor su gestión. Por ejemplo, la sisa — evidentemente no la alcabala o los pedidos- era un impuesto municipal extraordinario. El corregidor era requerido para vigilar o poner medios para que se cobrase una sisa. Ahora bien, la licencia para que se pudiese exigir tal impuesto era regia. Y esto era lo relevante. Lo mismo puede decirse de otros muchos asuntos. Incluso se aprecia en el plano judicial, partiendo de que los corregidores podían dictar resoluciones judiciales en su ámbito. Ahora bien, sólo juzgaban según la ley o según medidas que ellos no habían adoptado. Y además no eran la última instancia. La capacidad de recurrir a los tribunales regios en la legislación castellana era reconocida a personas vulnerables ${ }^{47}$ pero, además, cualquier vecino podía apelar y el sistema de alzadas era fluido, de modo que muchos casos acababan en los tribunales centrales, que, además, podían revocar las sentencias locales. A veces en un mismo documento se aprecia cómo un tribunal superior invalidaba la resolución local. Por ejemplo, un documento de 1482 a propósito de las deudas contraídas con los judíos permite comprobar cómo el corregidor había sentenciado a favor de estos, pero los labradores apelaron a la Audiencia Real y, tras varios pasos, esta sentenció a favor de los labradores, pero sin ser definitivo porque el Consejo Real avocó la causa. En cualquier caso, el corregidor quedó fuera de juego ${ }^{48}$. Cuantitativamente destaca el hecho de que los inputs en los que los reyes no solicitaron la intervención del corregidor de Ávila suponen

último tercio del siglo, como en este caso Ávila, aunque en otro contexto, parece que no desmiente en lo esencial aquella hipótesis.

47 Véase supra, nota 23.

48 7-12-1482, Documentación del Archivo Municipal de Ávila, 1988-1999, doc. 298. Como decía la carta regia, el corregidor debía inhibirse «fasta tanto que el dicho proçeso sea traýdo ante nos e al nuestro Consejo». También se aprecia en documentación de la Audiencia, 17-111492, ACH, Registro de ejecutorias, caja 50,5. 
el 54,2 \% de los documentos, en concreto 813 de 1.499, frente a los 365 en que sí se requirió la actuación del corregidor abulense, un 24,3\% $\%$.

La relegación del corregidor se dio en muchos asuntos. Y no sólo en las materias que, como decimos — política económica, minorías, guerra, régimen político, altas esferas jurisdiccionales...- escaparon a su incumbencia, sino en aquellas otras donde era activa la dinámica local. Por ejemplo, en los pleitos de términos, precisamente una de esas materias en las que los corregidores tenían atribuciones notables. En la abundante problemática abulense sobre ello es cierto que no faltan ocasiones en que a estos oficiales se les encomendó cumplir la normativa de las Cortes o las sentencias sobre restitución de comunales y términos ocupados. Pero no hay que olvidar que esta política frecuentemente se resolvía en tribunales centrales, que podían revocar sentencias locales, o en todo caso que era fruto del juego político y del diálogo rey-pecheros de la Tierra. Y ahí el corregidor solía ser mero ejecutor ${ }^{50}$, o eran otros oficiales - corregidores de otras ciudades, escribanos, jueces de términos ad hoc, personal de la corte...- los encargados de actuar, demostrando así que el corregidor no era necesario para esa tarea.

En tercer lugar, hay que destacar la especial vulnerabilidad que la posición del corregidor tenía en el mundo concejil. Es claro que, por arriba, el corregidor estaba a merced de los tribunales centrales y del poder regio, que era quien decidía su nombramiento, quien podía prescindir de sus servicios - destituirlo, como a Juan Flores en $1479^{51}$ — , quien podía hacerlo condenar por irregulari-

49 Se corresponden en la tabla con el patrón A y B. Menor importancia aún presenta el patrón $\mathrm{C}$, en el que los monarcas solicitaban una actuación concreta de las autoridades locales: 39 documentos del total de 1.499, apenas un 2'6 \%. En cuanto al patrón D, representa el 10'9 $\%$, con 164 documentos. Hubieran sido más, sin duda, si se hubiesen conservado libros de actas concejiles completos, véase nota 30 . Por su parte, el patrón E, donde están incluidas las actuaciones documentadas del corregidor no exigidas explícitamente por el poder superior, representan un 7'8 \%, exactamente 118 documentos.

${ }^{50}$ Esta relación de las fuerzas locales con el rey era lo verdaderamente importante para los términos ocupados, más que el corregidor. Este, sin duda, aparece y es destacable algún personaje como Álvaro de Santiesteban, MEMBRADO, 2018. Aunque es un indicador aleatorio y tosco, se aprecia que en un libro sobre comunalismo abulense, que recoge seis trabajos anteriores, mencionamos al corregidor hasta sesenta y siete veces, MONSALVO, 2010 (a lo que hay que añadir veintitrés menciones en un artículo no incluido en el libro, MONSALVO, 20052006), lo que demuestra que el papel del corregidor es un argumento importante en nuestro análisis. Ahora bien, en estos estudios hemos demostrado que más importante que el corregidor en el conflicto fueron otros actores y factores: poder regio centralizado, principio de legalidad concejil, capacidad política y reivindicativa de los pecheros de la Tierra, entre otros. A propósito de las decisiones que afectaban a los caballeros abulenses hacemos algunas referencias un poco más abajo.

51 22-9-1479, Documentación del Archivo Municipal de Ávila, 1988-1999, doc. 255. Por cohecho y otros delitos. 
dades — como a Álvaro de Santiesteban ${ }^{52}$ _, o no renovar su mandato. Y, en cualquier caso, someterlo al control externo mediante el juicio de residencia, que funcionaba eficazmente. Pero, por abajo, también tenía la presión de las fuerzas locales, particularmente del Regimiento ${ }^{53}$. Le ocurrió a Juan Chacón, corregidor en la primavera de 1475, que fue reprobado por los regidores bajo las acusaciones de ser sobornable y de carecer de aptitudes para el oficio. Juan Chacón había sido lugarteniente de Arnalte Chacón y luego lo fue de Gonzalo Chacón. A pesar de las protestas del Regimiento ${ }^{54}$, la reina Isabel mantuvo a Juan Chacón ${ }^{55}$. La capacidad de presión del Regimiento era una limitación importante del poder de los corregidores. La relación política realmente estratégica era la del poder regio con el Regimiento, pilares estables y necesarios del engranaje monarquía-concejo, mientras que el corregidor era una pieza contingente. No obstante, hay que reconocer que los monarcas no solían ceder ante las quejas del Regimiento, como ocurrió también en ese caso.

En cuarto lugar, el poder regio disponía de recursos humanos suficientes y cualificados - e hizo uso de ellos - para aplicarlos al ámbito local, en lo que parecería un ámbito competencial del corregidor. Se ha dicho antes que en los asuntos de términos los reyes enviaban jueces de términos temporales, pero, en general, en todos los asuntos fue habitual que alcaldes de la corte, escribanos de fuera, bachilleres o licenciados foráneos, corregidores de otras ciudades, comisionados variados, actuaran en Ávila y su Tierra por orden regia, ya fuera para tramitar procesos - mediante cartas compulsatorias, incitativas... - o con tareas de ejecución, dejando fuera de juego al corregidor local. Esta práctica era muy habitual. Pongamos un sólo ejemplo - hay muchos - de esta relegación de

52 5-1-1493, Documentación medieval abulense en el RGS..., 1993-1998, vol. VIII, doc. 1 (y Documentación medieval del Asocio..., 1990, doc. 193), y 8-3-1494, Documentación medieval abulense en el RGS..., 1993-1998, vol. IX, doc. 64.

${ }^{53}$ No sólo el Regimiento. Por ejemplo, la presión de las aljamas logró evitar que los corregidores hiciesen uso de un supuesto derecho a tomar ropas de cama y otros bienes de moros y judíos para su alojamiento cuando llegaban al cargo, un asunto que fue conflictivo entre 1476 y 1481 y en el que los reyes — y el Consejo Real — dieron razón a la aljama — y concejo abulense - frente a varios corregidores, Documentación del Archivo Municipal de Ávila, 19881999, docs. 205, 236, 250, 287, 289; y Documentación medieval abulense en el RGS..., 1993-1998, vol. I, docs. 59 y 95.

${ }^{54}$ El 8-9 de mayo de 1475 pretendían su revocación. Sugieren los regidores «que non usase más del dicho ofiçio, que pues agora bastava al dicho Alfonso Cota, alcalde», hasta que los reyes proveyeran. Decían de él «non es letrado nin tiene letras nin abilidad», que «non despacha synon vendidos por su presçio» y «resçibe dineros de amas las partes que ante él pleito an», que es «sobervio e áspero e de dura conversaçión», entre otros argumentos que acabaron influyendo en su revocación, Documentación del Archivo Municipal de Ávila, 1988-1999, docs. 150 y 151. Unos días después aceptarían a Juan Chacón, obedeciendo y cumpliendo la carta regia, 13-5-1475, Documentación del Archivo Municipal de Ávila, 1988-1999, doc. 157.

55 10-5-1475, Documentación del Archivo Municipal de Ávila, 1988-1999, doc.156. Los regidores no tuvieron más remedio que aceptarlo, véase nota anterior. 
funciones del corregidor frente a otros oficiales externos. Como ocurrió con Rodrigo Álvarez Maldonado. Los monarcas pusieron en sus manos muchos asuntos que, en teoría, deberían haber recaído en el corregidor abulense. Las Cortes de Toledo de $1480^{56}$ establecían que los reyes pudiesen enviar diputados, a modo de visitadores o veedores, a los concejos. En abril de 1481 estaba ya nombrado el mencionado personaje, que era regidor de Salamanca. Debía encargarse de revisar las cuentas de propios, comprobar si se hacían torres ilegales, supervisar la administración de justicia, las obras públicas, asegurarse de que los corregidores y justicias restituirían los términos, vigilar las derramas o asegurarse de que se pasasen los tributos regios ${ }^{57}$. No eran pocas tareas. Desde 1483 se encargaría además de preparar, en cumplimiento de leyes de Cortes, el traslado de los judíos a un barrio apartado, situación que resultó muy conflictiva. Por él pasaron también algunos asuntos de términos, saca del pan y otros muchos asuntos ${ }^{58}$ que se tradujeron en una amplia relación que los reyes señalaban en 1487 cuando exigían cumplir las recomendaciones de Álvarez Maldonado: petición de cuentas al escribano mayor de los pueblos, Francisco Pamo, ante la sospecha de irregularidades, denuncia por incumplimiento de obras en puente, absentismo y algunas otras irregularidades de algunos regidores, denuncias a los fieles, exigencia de respetar la legislación en materia de moralidad pública o incumplimiento de normas sobre judíos y moros. Esta última carta la dirigían los reyes al corregidor ${ }^{59}$ para que hiciera cumplir lo propuesto por Maldonado ${ }^{60}$. El caso es bastante elocuente y muestra cómo los reyes, si lo consideraban pertinente, recurrían a agentes distintos al corregidor local.

Como efecto de todas las posibilidades mencionadas anteriormente, se desprende, en quinto lugar, otra evidencia del análisis documental, la capacidad de los reyes de sacar al corregidor de la ecuación concejil cuando apreciaban que los poderosos locales podían influir en él para imponer sus intereses. $\mathrm{O}$ si atendían los monarcas reclamaciones de la población en este sentido. Se comprueba que muchos de los asuntos concejiles no tenían por qué estar hipotecados ante una eventual posición débil del corregidor local ante las fuerzas vivas de la ciudad. Como se ha visto, la monarquía tenía otros recursos — otros agentes, decisiones terminales, instancias centrales de resolución - para contener a los poderosos sin necesidad de hacerlo a través del corregidor.

Es paradigmático el caso de Pedro Dávila el Mozo, señor de las Navas y Villafranca, regidor eminente de Ávila, cabeza de su bando-linaje de San Juan, quizá

${ }^{56}$ Cortes de los antiguos reinos de León y Castilla, 1882, tomo IV: 137-138.

57 24-4-1481, Documentación del Archivo Municipal de Ávila, 1988-1999, doc. 288.

58 Documentación del Archivo Municipal de Ávila, 1988-1999, docs. 301, 304, 326; y Documentación medieval abulense en el RGS..., 1993-1998, vol. IV, doc. 27.

59 Según un patrón que hemos clasificado como B27.

${ }^{60}$ Documentación del Archivo Municipal de Ávila, 1988-1999, doc. 326. 
la persona más influyente de Ávila desde 1473 —en que heredó los estados señoriales y la influencia de su homónimo padre - hasta 1504, en que murió. Cerca de un centenar de documentos entre 1475 y 1500 tienen relación directa con él. Destacó por la usurpación de comunales, intentos de apropiarse de cotos redondos, incluso de señorializar lugares. Aparece en muchos documentos, como es lógico. Sin ser exhaustivos, diremos simplemente que todo lo que fue importante en la lucha del concejo y los pecheros contra sus usurpaciones, o las medidas que se adoptaron para impedirlas, para restituir bienes a su estatus —régimen comunal abierto, «régimen de herederos e vecinos, alixares.... ${ }^{61}$ — fue decidido por los reyes o los tribunales centrales, ya fuera en la Audiencia Real, frecuentemente, o en la corte y el Consejo Real, dependiendo de si las acusaciones tenían además un acento penal o jurisdiccional. Además, los reyes recurrieron frecuentemente para gestionar la tramitación en el ámbito local de estos casos a oficiales de la corte, escribanos de fuera o jueces ad hoc, entre otros, sin que tuviera un papel significativo en estas actuaciones el corregidor de Ávila ${ }^{62}$, quedando este

${ }^{61}$ Remito a numerosa información sobre estas cuestiones en MONSALVO, 2010. Asimismo, Manuel Fernando Ladero en Documentación medieval abulense en la Real Chancillería..., 2013, vol. III: 25-33. También Irene Ruiz Albi en Documentación medieval abulense en la Real Chancillería..., 2013, vol. IV: 27-33.

${ }^{62}$ Patrón A. Entre otras, orden regia para que el corregidor no prendiese a nadie por infracciones sobre términos ocupados ilegalmente, como Helipar, Quemada, Quintanar, Robledo Halcones o Las Navas de Galisancho, 20-2-1477, Documentación medieval abulense en el $R G S \ldots$, 1993-1998, vol. I, doc. 51 (véase la geografía de estos lugares en MONSALVO, 2010: 363). Numerosos emplazamientos varios para acudir a los tribunales regios por la usurpación de estos términos o por los abusos en Navalmoral o Burgohondo, o por las tropelías cometidas desde su fortaleza de El Risco - Sotalvo - (Documentación medieval abulense en el RGS..., 1993-1998, vol. II, doc. 83, Documentación medieval abulense en el RGS..., 1993-1998, vol. VII, doc. 42, Documentación del Archivo Municipal de Ávila, 1988-1999, doc. 404, entre otros). Aunque podrían ser asimiladas sus capacidades a las del corregidor, lo cierto es que se encargó al juez de residencia Fernando de Molina el caso del pleito de Pedro Dávila con los concejos de San Bartolomé y el Herradón, 4-4-1487, Documentación del Archivo Municipal de Ávila, 1988-1999, doc. 327 (Documentación medieval del Asocio..., 1990, doc. 147). Hay que mencionar también la orden de dejar libre el término de Navalsaúz, 3-3-1490, Documentación medieval abulense en el RGS..., 1993-1998, vol. VI, doc. 11; o las ejecutorias sobre Navalmoral y Burgohondo, 17-8-1490, Documentación medieval abulense en el RGS..., 1993-1998, vol. VI, doc. 48 y 49 (y en Documentación medieval del Asocio..., 1990, doc. 181); o la ratificación de las sentencias sobre Navalmoral, 17-8-1490, Documentación del Archivo Municipal de Ávila, 1988-1999, doc. 376; o la confirmación de sentencias y ejecutorias contra él por usurpación de Quemada, Valdegarcía, Robledo Halcones y otros términos, Documentación medieval abulense en el RGS..., 1993-1998, vol. VIII, doc. 1 (y Documentación medieval del Asocio..., 1990, doc. 193), o sobre Quintanar, Documentación medieval abulense en la Real Chancillería..., 2013, vol. IV, doc. 7 (y Documentación medieval del Asocio..., 1990, doc. 192 y Documentación del Archivo Municipal de Ávila, 1988-1999, doc. 387). Así como el encargo a un alcalde de casa y corte para ejecutar la sentencia sobre El Helipar - donde se reconocía provisionalmente parte de los derechos a Pedro Dávila - en lugar de dejar la causa en manos del corregidor, 8-2-1493, 
deliberadamente apartado de gran parte de los $\operatorname{casos}^{63}$, o convertido en mero agente de algunas diligencias menores, y siempre por mandato regio, o reducida su labor a llevar a cabo ciertas pesquisas y averiguaciones que acabarían en los tribunales regios. Incluso, aunque algún corregidor sentenció o se implicó bastante contra las usurpaciones de Pedro Dávila ${ }^{64}$ — eso sí, siempre respaldado por los reyes - , lo relevante es que los procesos acababan remitiéndose a los tribunales centrales, a los que apelaba sistemáticamente el regidor abulense. Al final, los tribunales solían dar la razón a «Ávila y sus pueblos». Eso sin contar las cartas de «amparo y seguro» que los reyes otorgaron a víctimas o amenazados por Pedro Dávila o sus hombres. El todopoderoso caballero quedaba así sometido al poder superior regio sin poder sacar partido de todo su potencial como miembro principal de la oligarquía urbana.

Documentación medieval abulense en el RGS..., 1993-1998, vol. VIII, doc. 11; e, igualmente, la ejecutoria sobre este lugar, 22-8-1493, Documentación del Archivo Municipal de Ávila, 1988-1999, doc. 411. Y la receptoría al corregidor de Arévalo — pero no al de Ávila, que sería el juez natural - para resolver nuevas alegaciones y hacer pesquisa sobre El Helipar, 20-11495, Documentación medieval abulense en el RGS..., 1993-1998, vol. XI, docs. 6 y 7. O la receptoría para un escribano de cámara para hacer las probanzas del pleito, de nuevo, del concejo y los pueblos contra él, 9-2-1495, Documentación medieval abulense en el RGS..., 19931998, vol. XI, doc. 12; 1-4-1495, Documentación medieval abulense en el RGS..., 1993-1998, vol. XI, doc. 41; y 5-9-1495, Documentación medieval abulense en el RGS..., 1993-1998, vol. XI, doc. 97. O las nuevas ejecutorias en relación con Pedro Dávila y Burgohondo, 22-12-1496, $\mathrm{ACH}$, Registro de ejecutorias, caja 107,18 y 17-3-1498, ACH, Registro de ejecutorias, caja 120,33. Sobre el término de Navalmoral, 20-3-1498, ACH, Registro de ejecutorias, caja 120,41.

${ }^{63}$ A veces se prohibió expresamente al corregidor intervenir en los casos, como se le hizo saber en las cartas de 1488 para que se inhibiera en los pleitos de varios concejos de la comarca de Pinares contra Pedro Dávila, Documentación del Archivo Municipal de Ávila, 1988-1999, docs. 337 y 338 .

${ }^{64}$ Ya en los primeros años del reinado, Juan del Campo aparece implicado en esta política de restituciones, 4-5-1477, Documentación del Archivo Municipal de Ávila, 1988-1999, doc. 223. Más tarde, el corregidor Álvaro de Santiesteban sentenció contra Pedro Dávila por Navalmoral, 6 a 26-3-1489, Documentación del Archivo Municipal de Ávila, 1988-1999, doc. 356; asimismo, 9-3-1489 Documentación medieval del Asocio..., 1990, doc.159. Y sobre Burgohondo, noviembre de 1489, Documentación del Archivo Municipal de Ávila, 1988-1999, doc. 367. También dictó sentencia sobre otros términos, Quemada, Quintanar, Helipar, Casa del Porrejon, Navas de Galinsancho, Robledo Halcones y Valdegarcía, 2-8-1490, Documentación medieval del Asocio..., 1990, doc. 175 y Documentación medieval abulense en el RGS..., 19931998, vol. VIII, doc. 1; o por Burgohondo y otros términos, 15-10 a 8-11-1490, Documentación medieval del Asocio..., 1990, doc. 185. Referencias a la actuación de este corregidor en MEMBRADO, 2014; 2018. MONSALVO, 2001; 2010: 391-392, 414-415. Álvaro de Santiesteban tuvo malas relaciones con Pedro Dávila: en un documento se quejaban los procuradores de este, «porque vos, el dicho corregidor, diz que sienpre avedes sydo e soys muy odioso e sospechoso al dicho Pedro Dávila e a sus cosas», 1490, Documentación medieval abulense en el $R G S \ldots, 1993-1998$, vol. VI, doc. 55. En todo caso, la última palabra la acababa teniendo siempre el Consejo Real. 
Situación semejante a la del citado señor de las Navas tuvieron otros caballeros-regidores, como los señores de Villatoro o Villanueva y San Román. Tampoco pudieron librarse de la justicia regia directa. Nos centraremos ahora en otro ejemplo, que muestra también la relegación relativa del corregidor, pero en este caso a propósito de decisiones que afectaban a una familia importante, pero que no era de la gran oligarquía urbana. Se trata de los Pamo. Los miembros de esta familia pertenecían a la elite de una importante aldea de Ávila, Fontiveros, la más grande de la mitad norte de la Tierra. Tenían influencias en su localidad - donde rivalizaban con los Cuba - pero también en la ciudad, donde contaban con el favor de Pedro Dávila, señor de las Navas. Francisco Pamo ocupaba de forma vitalicia en esta época, hasta su muerte en $1497^{65}$, la escribanía de los pueblos. Pero no fue sólo este personaje ${ }^{66}$ el protagonista de los desórdenes, sino también sus hermanos, Pedro, Cristóbal, Nuño, Fernando y María, casada con Fernando Tola, de otra familia de esa aldea. Los Pamo aparecen ya en 1475 acusados de construir una fortaleza ilegal en su aldea. No era más que el comienzo. Desde 1475 hasta 1494, actuando como caballeros locales con hombres armados a su servicio, y coaccionando al concejo aldeano, protagonizaron muchos incidentes violentos e ilegalidades que aquí nos interesan para apreciar el papel del corregidor abulense en el ejercicio de la justicia, tanto en el plano represivo como en el judicial, que constituyen el campo más genuino de las competencias y atribuciones asignadas de oficio a los corregidores. ¿Qué hicieron los Pamo? Además de la fortaleza ilegal, quizá destinada a usurpar Fontiveros, protagonizaron enfrentamientos con los Cuba durante los años setenta con resultado de «muertes», «robos», matanzas y rapiñas de ganado - miles de cabezas robadas-, o de caballos, así como «daños» severos que ellos y sus rivales provocaron tanto en Fontiveros como en las aldeas de Mancera, Mirueña — donde los Cuba quemaron algunas casas - y otras ${ }^{67}$; intimidación en 1483 a un tal Juan Rodríguez y su mujer, a la que indujeron los hombres de los Pamo a cometer adulterio con uno de ellos - Fernando Pamo-, burlarse del marido, destruir su casa, injuriar a la mujer; apropiación de los bienes de una herencia de los huérfanos cuyo tutor era Juan de la Plaza, que reclamó a los reyes; apropiación de los bienes, años después, de los hijos de este cuando murió; coerciones varias de los Pamo, regidores de la localidad, sobre sus vecinos y promoción de banderías en la aldea, hasta el punto de que en 1487

65 21-6-1497, Documentación del Archivo Municipal de Ávila, 1988-1999, doc. 465 y Documentación medieval abulense en el RGS..., 1993-1998, vol. XIII, doc. 38

${ }^{66}$ BELLO GAY, 2017. MONSALVO, 2006: 134, 151. C. Luis López se refiere también junto a otros asuntos - a estos hechos en Documentación medieval abulense en la Real Chancillería..., 2013, vol. I: 34-43.

${ }^{67}$ Sumando daños y pérdidas, el valor de los bienes afectados podía llegar a cerca de 500.000 mrs., Documentación medieval abulense en la Real Chancillería..., 2013, vol. I: 40. 
fueron desterrados de ella tras pesquisas. Después de cinco años de destierro, volvieron a protagonizar conflictos usando sus hombres armados, atacando en 1492 a los oficiales entonces existentes - Andrés de Cogollos-y provocando disturbios incluso en iglesias, como la de San Cipriano de la localidad, donde hasta María Pamo, con «estynto diabólico le dio de coçes» a la esposa de Andrés de Cogollos. Tras su condena por el Consejo Real en grado de revista, en 1493 resistieron a la justicia, pero tuvieron que afrontar penas de cárcel, destierros y compensaciones económicas a sus víctimas ${ }^{68}$. En todo esto ¿no debería haber sido protagonista el corregidor abulense?, ¿lo fue de hecho? Hemos comprobado que las principales decisiones que afectaron a $\operatorname{los} \mathrm{Pamo}^{69}$ fueron tomadas o por los reyes directamente o por tribunales centrales, no por el corregidor de Ávila ${ }^{70}$. El papel de este se limitó a tramitar procesos que resolvieron

${ }_{68}$ Referencias a todo ello en las notas siguientes.

${ }^{69}$ Incluido el perdón que dieron los reyes a Nuño Pamo tras su anterior apoyo a los portugueses al participar - y ser malherido - en la guerra de Granada, 4-7-1485, Documentación medieval abulense en el RGS..., 1993-1998, vol. III, doc. 80. Unos años después perdonaban a otro hermano, que también había apoyado a los portugueses, perdón que los reyes podían dar gracias a su poderío real absoluto, 10-12-1490, Documentación medieval abulense en el RGS..., 1993-1998, vol. VI, doc. 63.

${ }^{70}$ Según el patrón A de nuestra tabla. En la orden sobre el derribo de la fortaleza ilegal en Fontiveros los reyes no encargaron esta misión al corregidor, sino que comisionaron a un alcalde de la corte y miembro del Consejo Real para averiguar los hechos y derribar la torre, 18-2-1475, Documentación medieval abulense en el RGS..., 1993-1998, vol. I, doc. 10. Emplazamientos ante los alcaldes de corte tanto de los Pamo como los Cuba y sus hombres respectivos para aclarar las «muertes, robos e daños acaecidos», 23-11-1480, Documentación medieval abulense en el RGS..., 1993-1998, vol. II, doc. 86. Comisión al corregidor de Arévalo — no al de Ávila — para resolver los intentos de los Pamo varones de privar a su cuñado Fernando Tola de la dote de su esposa, María Pamo, 14-121486, Documentación medieval abulense en el RGS..., 1993-1998, vol. IV, doc. 57. Comisión a un «alguazil de la mi casa e corte» para resolver las injurias y ataques de los Pamo a Juan Rodríguez, tras el adulterio de su mujer, y actuaciones por no haberse cumplido las órdenes de prisión establecidas, 25-8-1483, Documentación medieval abulense en el RGS..., 1993-1998, vol. III, doc. 12 y 12-121483, Documentación medieval abulense en el RGS..., 1993-1998, vol. III, doc. 21. Emplazamiento y condena a Pedro Pamo por apropiarse de los bienes de los sobrinos de Juan de la Plaza, huérfanos, 26-3-1485, Documentación medieval abulense en el RGS..., 1993-1998, vol. III, doc. 63. Sentencia contra Pedro Pamo por haberse apropiado de esos bienes, 21-2-1487, Documentación medieval abulense en la Real Chancillería..., 2013, vol. I, doc. 23. Comisión regia a Antonio Álvarez de Amusco — un bachiller totalmente ajeno al corregimiento de Ávila — para averiguar los abusos de los Pamo en Fontiveros y otras partes, mientras dictaban que perdieran sus oficios y fueran desterrados cinco leguas de la localidad, 6-2-1487, Documentación medieval abulense en el RGS..., 1993-1998, vol. IV, doc. 61. Encargo de los reyes a un tal Fernando de Hoces, ajeno al corregimiento abulense, de la pesquisa y resolución de las violencias y disturbios protagonizados desde 1492 por los Pamo en su localidad, en la iglesia del pueblo, o por sus acciones contra el alguacil Cogollos, 30-5-1493, Documentación medieval abulense en el RGS..., 1993-1998, vol. VIII, docs. 48 y 49. Emplazamiento por las violencias de los Pamo hecho por un escribano de la corte, no por el corregidor, 22-8-1493, Documentación medieval abulense en el RGS..., 1993-1998, vol. IX, doc. 11; finalmente, tras resistir a la justicia, les llegaban las condenas de cárcel y destierro a varios miembros de la familia Pamo, 26-10-1493, Documentación medieval abulense en el RGS..., 1993-1998, vol. IX, doc. 33. 
los alcaldes de la corte y el Consejo Real ${ }^{71}$, a cumplir órdenes regias o a ejecutar sentencias contra ellos ${ }^{72}$, o ni siquiera eso, porque las ejecutorias iban dirigidas a la justicia en general, y no asignaban una misión concreta al corregidor en particular, hasta el punto de que cualquier otra autoridad podía ejercer esa función. Como se decía en algún documento, en concreto de Pedro Pamo, era «poderoso e enparentado asý en la dicha çibdad de Ávila commo en la dicha Fontiveros», de modo que quien reclamara allí no podría «alcançar conplimiento de justicia nin las justiçias della ge la farían nin podrían fazer» ${ }^{73}$.

Estas situaciones en las que comprobamos que los casos se resolvían en la corte, la Audiencia o el Consejo Real, sorteando así la justicia local, susceptible de ser presionada por los poderosos, fueron frecuentes. Pero es preciso matizar. Como vemos, los corregidores podían quedar fuera de casos en que podían no ser imparciales, o cuando corrían el riesgo de ser presionados. Pero no hay que olvidar que otras veces el corregidor fue precisamente el ariete que emplearon el concejo y los «pueblos» — organización de la Tierra - para recuperar términos ocupados ilegalmente, precisamente porque el corregidor era garantía frente a la «mengua de justicia» que provocaban los oligarcas locales ${ }^{74}$.

¿No hay algo contradictorio o paradójico en todo esto? En realidad, no. La clave es que detrás del juego local de poderes se situaba en el reinado de Isabel una potente monarquía capaz de atender, amén de los intereses particulares, algunas demandas de interés general o de la población concejil, capaz de dialogar políticamente con las oligarquías locales, y de complacer sus intereses, sí, pero otras veces decidida a contener sus desmanes. Para ello fue decisivo el control regio de la justicia. Ahora bien, esta justicia la ejercieron los reyes con el corregidor o sin él. La clave no estaba en la figura, sino en la versatilidad del sistema político. Porque si el corregidor no servía para estos propósitos, todo un conjunto de instancias superiores y tribunales centralizados - Audiencia, alcaldes de corte, Consejo Real, además de jurisdicciones especiales de la Hermandad, la Mesta o la Inquisición - podía ejercer esa justicia regia que con tanta efectividad destacó en el reinado de los Reyes Católicos.

${ }^{71}$ Aunque sí recibió receptoría para hacer algunas probanzas en Fontiveros, diciembre 1480, Documentación medieval abulense en el RGS..., 1993-1998, vol. III, doc. 6

${ }^{72}$ Por ejemplo, durante el destierro de los Pamo de Fontiveros en 1487 el corregidor velaría para que no hubiera bandos locales entre los oficiales concejiles nuevos puestos en el lugar, 17-8-1487, Documentación medieval abulense en el RGS..., 1993-1998, vol. IV, doc. 69. Casi lo más relevante fue la orden regia de hacer cumplir la sentencia por la que los alcaldes de corte habían condenado a los Pamo a pagar 250.610 mrs. a la familia de Diego de Fontiveros, al que habían entrado en su casa, destruido bienes y robado dinero y otros objetos de valor, 2-7-1500, Documentación medieval abulense en el RGS..., 1993-1998, vol. XVI, doc. 41

73 26-3-1485, Documentación medieval abulense en el RGS..., 1993-1998, vol. III, doc. 63.

${ }^{74}$ Sobre todo, contaron con la confianza de los pecheros. Se resalta, entre otras ocasiones, en MONSALVO, 2001: 106-107; 2005-2006: 73-74; 2010: 307-309. 

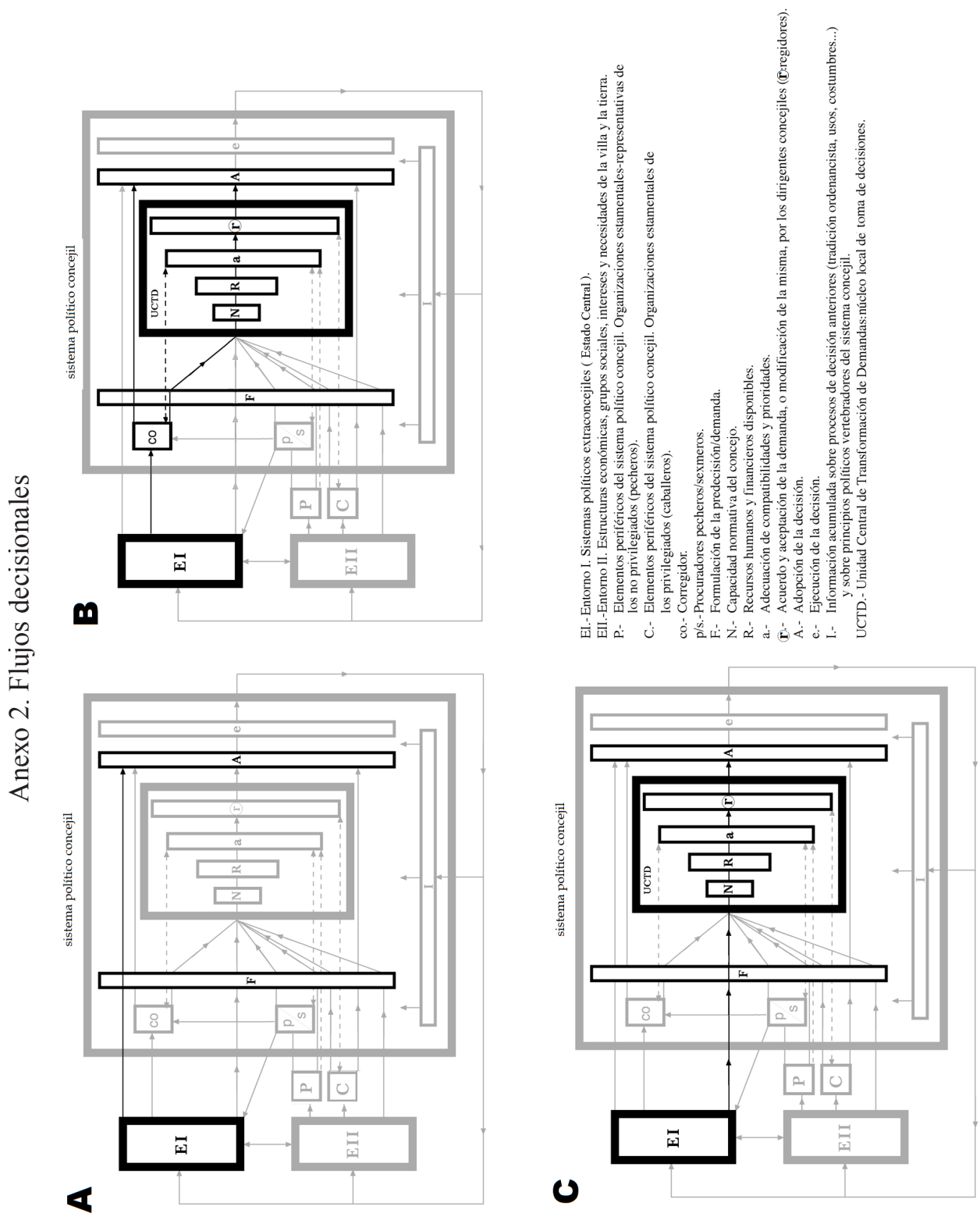
En definitiva, si se comparan las diferentes vías de la toma de decisiones procedentes del poder superior se aprecia que el recurso al corregidor era sólo una de las posibilidades. Los reyes y los tribunales regios podían utilizar al corregidor, en efecto. Pero también podían imponer una determinada decisión unilateralmente, bien cuando el asunto sobrepasaba el umbral competencial práctico del concejo, bien sirviéndose de otros oficiales diferentes al corregidor local. Además, los reyes podían negociar o remitir un determinado asunto al Regimiento, sin que tampoco en este caso fuera necesaria la intervención de dicho oficial ${ }^{75}$.

\section{A MOdo DE CONCLUSIÓN}

Con independencia de cuáles fueran las competencias, atribuciones y prerrogativas del oficio, el corregidor destaca como un instrumento del poder regio. Y no espurio ni honorífico. Era efectivo para aplicar las directrices del estado monárquico. Esto resulta indudable.

Ahora bien, creemos haber demostrado, o al menos sugerido con fundamento, que, como pieza del engranaje de la monarquía, el corregidor no resultaba necesario o imprescindible. Esto es debido a que el poder regio y los órganos centrales de gobierno y justicia de la monarquía disponían de otros recursos suficientes y competentes para suplir las funciones del corregimiento o, si era el caso, para rebajar precisamente la implicación administrativa o judicial de este oficial. Máxime cuando los reyes consideraban - por sugerencia de parte normalmente, esto es, a petición de las fuerzas locales o de los interesados en los pleitos - que estaba en tela de juicio su imparcialidad, así como también cuando el oficial podía ser objeto de presiones en el ámbito urbano. Otras veces simplemente los reyes encomendaban al corregidor tareas secundarias: mera ejecución de sentencias, presentación de escrituras o realización de pesquisas cuyo destino era su remisión a los tribunales centrales. Precisamente porque era en estas instancias terminales donde se acababan resolviendo los procesos.

El corregidor de las ciudades de realengo, en este caso Ávila, soportaba desde arriba la presión de los reyes. Lo hemos podido corroborar. De los reyes dependía su nombramiento y su control, que por otra parte iba más allá del mero juicio de residencia. Pero, desde abajo, las fuerzas concejiles, en concreto los miembros del Regimiento, comprimían también el margen de actuación de

75 Pueden apreciarse estas posibilidades en el Anexo 2. Los patrones decisionales se corresponden con la prevalencia, respectivamente, de la decisión unilateral regia (A), de la vía que utilizaba el requerimiento regio al corregidor (B) y de la que hacía pasar el input regio por el Regimiento (C). La explicación de los elementos del sistema en referencias citadas en la nota 7. 
los corregidores, dada la capacidad de diálogo y entendimiento concejil con el poder regio, que formaba parte de la cultura política de la élite gubernamental concejil en la época. Aún más importante es destacar que el poder regio pudo utilizar otros recursos para aplicar las mismas medidas y actuaciones de las que se solían encargar los corregidores cuando así se les requería. De hecho, se prefería a veces asignar los casos a escribanos foráneos, a alcaldes de la corte, a oidores de la Audiencia, a jueces del Consejo, a jueces eclesiásticos, a corregidores de otros municipios o a bachilleres o letrados de confianza encargados ad hoc. Ellos podían tramitar los procesos o hacer cumplir órdenes regias tan bien o mejor que el corregidor local. Todo ello redundaba, sin duda, en la independencia o gran autonomía, al menos, de la justicia regia, un valor que, gracias a estos engranajes decisionales detectados, parecía afirmarse en la época y en estos medios concejiles.

Por otra parte, cuando actuaba, el corregidor lo hacía generalmente sin depender de las fuerzas oligárquicas locales, ya que su poder no emanaba de ellas, sino de la monarquía. En general, si entre los «principios políticos vertebradores del sistema concejil» - entendemos este como un cruce o concurrencia entre ellosse encuentran, como hemos señalado en otros trabajos, principios que no se basaban en lo «estamental» ni en lo «privado», tales como principios de «justicia»y «legalidad», hay que reconocer que el corregimiento se asoció netamente con ellos, mucho más que otros oficios como los regidores, los procuradores, los sexmeros y otros, todos ellos muy sesgados por su composición social y su posición sistémica. Esta orientación más autónoma del poder de los corregidores, de hecho, así fue percibida muchas veces en las ciudades de Castilla. Podría decirse por ello que el corregimiento, por su existencia, pero también por la praxis de que fue objeto el oficio, contribuyó a sostener la confianza que la sociedad política y la gente común depositaron en la monarquía durante el reinado de Isabel, lo que redundó en un reforzamiento de su legitimidad.

\section{BibliogRAFÍA}

Asenjo González, María, «Función pacificadora y judicial de los corregidores en las villas y ciudades castellanas a fines de la Edad Media», Medievalista on line, 18 (2015).

Asenjo González, María, «El corregidor en la ciudad. La gestión de su oficio y la construcción del "habitus", a fines del siglo XV y principios del XVI», Studia Historica. Historia Moderna, 39/1 (Salamanca, 2017): 89-124.

Bello Gay, Rocío, «Alrededor de la figura controversial de Francisco Pamo», Fundación, 13 (Buenos Aires, 2016-2017): 50-63.

Bermúdez Aznar, Agustín, El corregidor en Castilla durante la Baja Edad Media (1348-1474), Murcia, Universidad de Murcia, 1974.

Códigos españoles concordados y anotados, Madrid, Rivadeneyra, 1850, tomo VII. 
Cortes de los antiguos reinos de León y Castilla, Madrid, Real Academia de la Historia, 1863 (tomo II) y 1882 (tomo IV).

Documentación del Archivo Municipal de Ávila, vol. I (1256-1474), ed. de Ángel Barrios, Blas Casado, Carmelo Luis López y Gregorio Del Ser; vol. II (1436- 1477), ed. de Tomás Sobrino; vol. III (1478-1487), ed. de Carmelo Luis López; vol. IV (1488-1494), ed. de Blas Casado; vol. V (1495-1497), ed. de Gregorio Del Ser; vol. VI (1498-1500), ed. de José Miguel López Villalba, Ávila, Institución Gran Duque de Alba / Diputación Provincial de Ávila, 1988-1999, 6 vols.

Documentación medieval abulense en la Real Chancillería de Valladolid: Registro de Ejecutorias, vol. I (1477-1487), ed. de Carmelo Luis López; vol. II (1487-1488), ed. de José Manuel Ruiz Asencio; vol. III (1489-1490), ed. de Manuel Fernando Ladero Quesada; vol. IV (1490-1491), ed. de Irene Ruiz Albi, Ávila, Institución Gran Duque de Alba / Diputación Provincial de Ávila, 2013, 4 vols.

Documentación medieval abulense en el RGS (Registro General del Sello), 1467-1500, vol. I, ed. de José Luis Martín Rodríguez; vol. II, ed. de Carmelo Luis López; vol. III, ed. de Tomás Sobrino; vol. IV, ed. de Gregorio del Ser; vol. V, ed. de Blas Casado Quintanilla; vol. VI, ed. de José Antonio Canales; vol. VII, ed. de José Luis Martín Rodríguez; vol. VIII, ed. de Carmelo Luis López; vol. IX, ed. de Carmelo Luis López; vol. X, ed. de José María Herráez Hernández; vol. XI, ed. de Juan Hernández Pierna; vol. XII, ed. de Tomás Sobrino Chomón; vol. XIII, ed. de María Dolores Cabañas; vol. XIV, ed. de Jose María Monsalvo Antón; vol. XV, ed. de Juan Ignacio García Pérez; vol. XVI, ed. de Juan Jacinto García Pérez, Ávila, Institución Gran Duque de Alba / Diputación Provincial de Ávila, 1993-1998, 16 vols.

Documentación medieval del Archivo Municipal de San Bartolomé de Pinares (Ávila), edición de Gregorio Del Ser, Ávila, Institución Gran Duque de Alba / Diputación Provincial de Ávila, 1987.

Documentación medieval en Archivos Municipales Abulenses (Aldeavieja, Avellaneda, Bonilla de la Sierra, Burgohondo, Hoyos del Espino, Madrigal de las Altas Torres, Navarredonda de Gredos, Riofrío, Santa Cruz de Pinares y El Tiemblo), edición de Gregorio Del Ser, Ávila, Institución Gran Duque de Alba / Diputación Provincial de Ávila, 1998.

Documentación medieval del Asocio de la Extinguida Universidad y Tierra de Ávila, edición de Carmelo Luis López, y Gregorio Del Ser, Ávila, Institución Gran Duque de Alba / Diputación Provincial de Ávila, 1990, 2 vols.

González Alonso, Benjamín, El corregidor castellano (1348-1800), Madrid, Instituto de Estudios Administrativos, 1970.

Guerrero Navarrete, Yolanda, «La política de nombramiento de corregidores en el siglo XV: entre la estrategia regia y la oposición ciudadana», Anales de la Universidad de Alicante. Historia Medieval, 10 (Alicante, 1994-1995): 99-124.

Guerrero Navarrete, Yolanda, «Orden público y corregidor en Burgos (siglo XV)», Anales de la Universidad de Alicante. Historia Medieval, 13 (Alicante, 20002002): 59-102.

Jara Fuente, José Antonio, «Entre el conflicto y la cooperación: la ciudad castellana y los corregidores, praxis de una relación política hasta la monarquía isabelina», Studia Historica. Historia Moderna, 39/1 (Salamanca, 2017): 53-87. 
Luchía, Corina, «Acción política, conflicto y toma de decisiones en una comunidad urbana: consideraciones a partir de las actas de sesiones del concejo abulense (1497-1500)», Studia Historica. Historia Medieval, 36/2 (Salamanca, 2018): 199-218.

Lunenfeld, Marvin, Los corregidores de Isabel la Católica, Barcelona, Labor, 1989.

Membrado, Sofía, «Los corregidores en los pleitos por la tierra y otros conflictos abulenses. Apuntes sobre las cualidades del oficio (1475-1500)», Anuario del Centro de Estudios Históricos Prof. C.A. Segreti, 1/14 (Buenos Aires, 2014): 77-92.

Membrado, Sofía, «El corregimiento en la Baja Edad Media. El caso de Álvaro de Santisteban (1488-1493)», Magallánica. Revista de Historia Moderna, 8 (Buenos Aires, 2018): 181-209.

Membrado, Sofía, «Acusaciones, transgresiones y delitos en torno a los oficiales de la justicia regia en el obispado de Ávila (1475-1503)», Sociedades Precapitalistas, 9 (2019) revista on line.

Monsalvo Antón, José María, El sistema político concejil. El ejemplo del señorío medieval de Alba de Tormes y su concejo de villa y tierra, Salamanca, Universidad, 1988.

Monsalvo Antón, José María, «Usurpaciones de comunales: conflicto social y disputa legal en Ávila y su Tierra durante la Baja Edad Media», Historia Agraria, 24 (Murcia, agosto 2001): 89-122.

Monsalvo Antón, José María, «Gobierno municipal, poderes urbanos y toma de decisiones en los concejos castellanos bajomedievales (consideraciones a partir de concejos salmantinos y abulenses)», Las sociedades urbanas en la España medieval (XXIX Semana de Estella, 2002), Pamplona, Gobierno de Navarra, 2003: 409-488.

Monsalvo Antón, José María, «Percepciones de los pecheros medievales sobre usurpaciones de términos rurales y aprovechamientos comunitarios en los concejos salmantinos y abulenses», Edad Media. Revista de Historia, 7 (Valladolid, 20052006): 37-74.

Monsalvo Antón, José María, «El realengo y sus estructuras de poder durante la Baja Edad Media», VV. AA., Historia de Avila. Tomo III. La Baja Edad Media (Siglos $X I V y X V)$, Ávila, Institución Gran Duque de Alba, 2006: 70-172.

Monsalvo Antón, José María, Comunalismo concejil abulense. Paisajes agrarios, conflictos y percepciones del espacio rural en la Tierra de Ávila y otros concejos medievales, Ávila, Diputación Provincial, 2010.

Ordenanzas medievales de Ávila y su Tierra, editado por José María Monsalvo, Ávila, Institución Gran Duque de Alba /Diputación Provincial de Ávila, 1990.

Polo Martín, Regina, El régimen municipal de la Corona de Castilla durante el reinado de los Reyes Católicos (organización, funcionamiento y ámbito de actuación), Madrid, Colex, 1999.

Recibido: $31 / 05 / 2020$

Aceptado: 10/04/2021 
